\title{
Bibliometric analysis of European publications between 2001 and 2016 on concentrations of selected elements in mushrooms
}

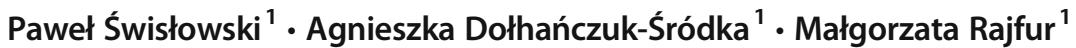

Received: 14 November 2019 / Accepted: 30 March 2020 / Published online: 23 April 2020

(C) The Author(s) 2020

\begin{abstract}
This article presents a bibliometric study of 200 European publications released between 2001 and 2016, about the contamination of mushrooms by selected elements. The analysis includes figures on the type of analyte, its concentration, the species of fungi, and its country of origin. In the literature review, 492 species of mushrooms (wild-growing and cultured) found in 26 European countries and their concentration of 74 associated elements were analysed. The papers, which dealt mainly with the heavy metal $(\mathrm{Cd}, \mathrm{Cu}, \mathrm{Fe}, \mathrm{Pb}$, and $\mathrm{Zn})$ concentrations of mushrooms, primarily came from Turkey, Poland, Spain, and the Czech Republic. More than $50 \%$ of the publications provided data about edible mushrooms. The results of the bibliometric analysis showed that over the 16 years, European research on fungal contamination by selected analytes has not lessened in popularity and is ongoing. Many of the studies underlined the need to assess the risk to human health arising from the consumption of contaminated mushrooms taken from various habitats. These results were the effect of, among other things, the strong interest in studies carried out on edible species, in which concentrations of mainly heavy metals that are dangerous to health and are marked were indicated $(\mathrm{Cd}, \mathrm{Pb}$, and $\mathrm{Hg})$.
\end{abstract}

Keywords Mushrooms $\cdot$ Heavy metals $\cdot$ Review $\cdot$ Bibliometric analysis

\section{Introduction}

Due to their organoleptic (taste) characteristics, mushrooms are a valuable product that are used in a range of dishes. The dry matter content is very low, usually around $100 \mathrm{~g} / \mathrm{kg}$. The low proportion of protein, fat, and carbohydrates result in a low nutritional and energy value. The potassium and phosphorus content of the fungi is higher than in most vegetables. The mushroom concentrates nutrients and minerals from the soil through the hyphae; however, they are not actively taken in from the air (Kalač 2009; Falandysz 2017). Mushrooms contain microelements that are indispensable for the functioning

Responsible Editor: Philippe Garrigues

Electronic supplementary material The online version of this article (https://doi.org/10.1007/s11356-020-08693-5) contains supplementary material, which is available to authorized users.

Paweł Świsłowski

swislowskip@gmail.com

1 Institute of Environmental Engineering and Biotechnology, University of Opole, B. Kominka 6a Street, 45-032 Opole, Poland of the human organism, but they can also concentrate heavy metals such as cadmium, mercury, and lead (Demirbaş 2001b). The fruiting bodies of edible mushrooms might contain high concentrations of macro- and micro-elements. The ability to take up high amounts of trace elements results from the specific structure of the mycelium: the uncovered surface of the vegetative cells and the hyphae's large surface area (Işiloğlu et al. 2001a). Generally, in the fruiting body of the mushrooms, heavy metals are stored bound to proteins, especially to low molecular weight ones (Cuny et al. 2001; Demirbas 2001a). It was evidenced that the uptake of metals from soil is a species characteristic and the level of concentration of individual microelements in the fungi is genetically conditioned (Işiloğlu et al. 2001b).

The papers included in this bibliometric analysis (literature reviews in the database) are concerned with the quantification of some important elements present in the fruiting body of some mushrooms; therefore, they contain data only about the concentration ranges of these elements. This article presents a new approach to the presentation and analysis of data on concentrations of selected elements in mushrooms. The abovementioned publications were categorised according to their year of issue, the author's country of origin, and the most 
Table 1 List of authors of works from the period 2001 to 2016

Year Authors

Number of

Number of journals

countries

2001 Blanuša et al. 2001; Cuny et al. 2001; Demirbaş 2001a, b; Ișiloğlu et al. 2001a; b; Falandysz et al. 2001a; b; Falandysz and Bielawski 2001; Marzano et al. 2001; Mattila and Ko 2001; Zimmermannová et al. 2001

2002 Baldrian and Gabriel 2002; Demirbaș 2002; Dernovics et al. 2002; Falandysz et al. 2002a; b; Larsen et al. 2002; Lodenius et al. 2002; Mietelski et al. 2002; Ott et al. 2002; Sivrikaya et al. 2002; Svoboda et al. 2002; Collin-Hansen et al. 2002 Falandysz et al. 2003a; b; Perkiömäki et al. 2003; Hatvani and
Kalač 2003; Tüzen 2003; Vetter 2003a, b; Yilmaz et al. 2003

2004 Colpaert et al. 2004; Isildak et al. 2004; Krupa and Kozdrój 2004; Malinowska et al. 200 Mendil et al. 2004; Moreno-Rojas et al. 2004; Muller et al. 2004; Nikkarinen and Mertanen 2004; Řanda and Kučera 2004; Turkekul et al. 2004; Vetter 2004; Yeșil et al. 2004

2005 Borovička et al. 2005; Carvalho et al. 2005; Collin-Hansen et al. 2005a, b; Díaz Huerta et al. 2005; Fomina et al. 2005; García et al. 2005; Mendil et al. 2005; Rudawska and Leski 2005a; b; Soeroes et al. 2005; Soylak et al. 2005; Tüzen and Soylak 2005; Vetter 2005a, b; Vetter and Berta 2005
Croatia, 1

Finland, 1

France, 1

Italy, 1

Poland, 2

Slovakia, 1

Sweden, 1

Turkey, 4

Czech Republic, 2

Denmark, 1

Finland, 1

Germany, 1

Hungary, 1

Norway, 1

Poland, 2

Ukraine and Spain,

Turkey, 2

Belgium, 1

Czech Republic, 1

Finland, 1

Germany, 1

Hungary, 3

Norway, 1

Poland, 2

Spain, 1

Turkey, 2

Belgium, 2

Czech Republic, 1

Finland, 1

Hungary, 1

Poland, 2

Spain, 1

Turkey, 4
Archives of Environmental

Contamination and Toxicology, 2

Ekologia (Bratislava), 1

Environmental Research, 1

Food Additives \& Contaminants, 1

Food Chemistry, 3

Journal of Agricultural and Food Chemistry, I

Journal of AOAC International, 1

Polish Journal of Environmental Studies, 1

Water, Air, and Soil Pollution, 1

Analytical and Bioanalytical

Chemistry, 1

Applied Radiation and Isotopes, 1

Archives of Environmental Contamination and Toxicology, 1

Bulletin of Environmental Contamination and Toxicology, 1

Environment International, 1

FEMS Microbiology Ecology, 1

FEMS Microbiology Letters, 1

Food Additives and Contaminants, 1

Food Chemistry, 3

Geochemistry Exploration

Environment Analysis, 1

Archives of Environmental

Contamination and Toxicology, 1

Bulletin of Environmental

Contamination and Toxicology, 1

Canadian Journal of Forest

Research, 1

Ecotoxicology and Environmental Safety, 1

European Food Research and Technology, 1

Food Chemistry, 2

Journal de Physique IV France, 1

Microchemical Journal, 1

New Phytologist, 1

The Science of the Total Environment, 1

Turkish Journal of Botany, 1

Water, Air, and Soil Pollution, 1

Bulletin of Environmental

Contamination and Toxicology, 1

European Food Research and

Technology, 1

Food Chemistry, 5

Journal of Food Composition and Analysis, 1

Journal of Radioanalytical and

Nuclear Chemistry, 1

New Phytologist, 2

World Journal of Microbiology \&

Biotechnology, 1

Belgium, Ireland, and Analytica Chimica Acta, 1

Great Britain, 1 Analytical Sciences, 1

Czech Republic and Slovakia, 1

Hungary, 4

Norway, 2

Poland, 2

Portugal, 1
Bulletin of Environmental

Contamination and Toxicology, 1

Food Chemistry, 4

Food Control, 2

Journal of Chemical Technology and

Biotechnology, 1 
Table 1 (continued)

Year Authors
Number of

countries
Number of journals

Spain, 2

Turkey, 3

2006 Benbrahim et al. 2006; Borovička et al. 2006; Cocchi et al. 2006; Sesli and Dalman 2006; Czech Republic, 1 Konuk et al. 2006; Malinowska et al. 2006; Sesli and Tuzen 2006; Moilanen et al. 2006; Czech Republic and Sesli 2006; Svoboda et al. 2006; Weeks et al. 2006

2007 Borovička and Řanda 2007; Borovička et al. 2007; Falandysz and Bielawski 2007; Falandysz et al. 2007; Figueiredo et al. 2007; Isildak et al. 2007; Komárek et al. 2007; Melgar et al. 2007; Nováčková et al. 2007; Omil et al. 2007; Ouzouni et al. 2007; Tüzen et al. 2007; Yamac et al. 2007

2008 Chudzyński and Falandysz 2008; Ertugay and Bayhan 2008; Falandysz and Gucia 2008; Falandysz et al. 2008; Johansson et al. 2008; Sesli et al. 2008; Svoboda and Chrastný 2008; Tasdemir et al. 2008; Yağiz et al. 2008; Žunić et al. 2008

2009 Brzostowski et al. 2009; Campos et al. 2009; Chudzyński et al. 2009; Duran et al. 2009; García et al. 2009; Gençcelep et al. 2009; Gonzálvez et al. 2009; Guillén et al. 2009; Gursoy et al. 2009; Melgar et al. 2009; Ouzouni et al. 2009; Krpata et al. 2009; Gorbunova et al. 2009; Elekes et al. 2009

2010 Borovička et al. 2010a; b; Çayir et al. 2010; Ertugay and Bayhan 2010; Frankowska et al. 2010; Karadeniz and Yaprak 2010; Ozturk et al. 2010; Radulescu et al. 2010a; b; c; Sarikurkcu et al. 2010; Zhang et al. 2010
Slovakia, 1

Finland, 1

France, 1

Great Britain, 1

Italy, 1

Poland, 1

Turkey, 4

Czech Republic, 3

Czech Republic and Slovakia, 1

Greece, 1

Poland, 2

Portugal, 1

Spain, 2

Turkey, 3

Czech Republic, 1

Poland, 3

Serbia, 1

Sweden, 1

Turkey, 4

Austria, 1

Greece, 1

Poland, 2

Romania, 1

Russia, 1

Spain, 5

Turkey, 3

Czech Republic, 2

Poland, 2

Romania, 3

Turkey, 5
Mycologia, 1

Mycological Research, 3

Science of the Total Environment, 1 Soil Biology \& Biochemistry, 1

Asian Journal of Chemistry, 2

Chemosphere, 1

Environmental Pollution, 1

Food Additives \& Contaminants, 1

Food Chemistry, 3

Forest Ecology and Management, 1

Fresenius Environmental Bulletin, 1

Pakistan Journal of Botany, 1

Analytical Letters, 1

Ekologia (Bratislava), 1

Environment International, 1

Food Chemistry, 2

Food Control, 1

Journal of Agricultural and Food Chemistry, 1

Journal of Environmental Science and Health, Part A, 1

Journal of Food Composition and Analysis, 1

Mycological Progress, 1

Mycological Research, 1

Science of the Total Environment, 2

Chemosphere, 1

Environmental Geochemistry and Health, 1

Food Additives \& Contaminants:

Part A, 1

Fresenius Environmental Bulletin, 1

Journal of Environmental

Radioactivity, 1

Journal of Environmental Science and Health, Part A, 1

Journal of Hazardous Materials, 2

Journal of Microbiology and

Biotechnology, 1

Soil Biology \& Biochemistry, 1

Annals. Food Science and Technology, 1

Biometals, 1

Bulletin of Environmental

Contamination and Toxicology, 1

Chemical Analysis, 1

Contemporary Problems of Ecology, 1

Environmental Pollution, 1

Food and Chemical Toxicology, 1

Food Chemistry, 3

Journal of Hazardous Materials, 2

Science of the Total Environment, 2

African Journal of Agricultural

Research, 1

Biological Trace Element Research, 1

Bulletin of Environmental

Contamination and Toxicology, 1

Desalination, 1

Food Additives \& Contaminants:

Part B, 1

Food and Chemical Toxicology, 1 
Table 1 (continued)

Year Authors
Number of countries
Number of journals
2011 Ayaz et al. 2011; Borovička et al. 2011; Brzostowski et al. 2011; Busuioc et al. 2011; Campos and Tejera 2011; Chudzyński et al. 2011; Costa-Silva et al. 2011; Kula et al. 2011; Rieder et al. 2011; Osobová et al. 2011; Sarikurkcu et al. 2011; Stihi et al. 2011

2012 Aloupi et al. 2012; Cremades et al. 2012; Giannaccini et al. 2012; Gryndler et al. 2012; Gucia et al. 2012; Maćkiewicz and Falandysz 2012; Milinkovic et al. 2012; Mititelu et al. 2012; Sarikurkcu et al. 2012; Șen et al. 2012; Škrbić et al. 2012; Vinichuk 2012
Czech Republic, 1 Greece, 1

Italy, 1

Poland, 2

Romania, 1

Serbia, 2

Spain, 1

Sweden, 1

Turkey, 2
Daillant et al. 2013; García-Delgado et al. 2013; García et al. 2013; Gramss and Voigt 2013; Belgium, 1 Gwynn et al. 2013; Miklavčič et al. 2013; Mirończuk-Chodakowska et al. 2013; Özcan et al. 2013; Petkovšek and Pokorny 2013; Ruytinx et al. 2013; Severoglu et al. 2013; Slávik et al. 2013; Zhang et al. 2013
France, 1

Germany, 1

Norway, 1

Poland, 2

Slovakia, 1

Slovenia, 2

Spain, 2

Turkey, 2
Journal of Consumer Protection and Food Safety, 1

Journal of Radioanalytical and Nuclear Chemistry, 1

Ovidius University Annals of Chemistry, 1

Romanian Biotechnological Letters, 1 Science of the Total Environment, 1 Soil Biology \& Biochemistry, 1

Biological Trace Element Research, 1 Biometals, 1

Bulletin of Environmental Contamination and Toxicology, 1 Bulletin UASVM Agriculture, 1

Environmental Pollution, 1

Environmental Science and Pollution Research, 1

Food and Nutrition Sciences, 1

Food Chemistry, 3

Journal of Environmental Science and Health, Part A, 1

New Phytologist, 1

Biological Trace Element Research, 1

Biometals, 1

Bulletin of Environmental

Contamination and Toxicology, 1

Ecological Indicators, 1

Ecology of Food and Nutrition, 1

Ecotoxicology and Environmental Safety, 1

Environmental Monitoring and Assessment, 1

Environmental Science and Pollution Research, 1

Food Chemistry, 1

ISRN Ecology, 1

Journal of Environmental Protection and Ecology, 1

Proceedings of 6th Central European Congress on Food, 1

Bulletin of Environmental Contamination and Toxicology, 1

Environmental Monitoring and Assessment, 1

Environmental Research, 1

Environmental Science and Pollution Research, 1

Food and Chemical Toxicology, 1

International Journal of

Environmental Science and Technology, 1

Journal of Environmental Radioactivity, 1

Journal of Microbiology, Biotechnology and Food Sciences, 1

Journal of Mountain Science, 1

Journal of Radioanalytical and Nuclear Chemistry, 1

Metallomics, 1

Polish Journal of Environmental Studies, 1

Science of the Total Environment, 1 Applied Geochemistry, 1 
Table 1 (continued)

\begin{tabular}{|c|c|c|c|}
\hline Year & Authors & $\begin{array}{l}\text { Number of } \\
\text { countries }\end{array}$ & Number of journals \\
\hline & $\begin{array}{l}\text { Baumann et al. 2014; Borovička et al. 2014; Drewnowska et al. 2014; Dryżałowska and } \\
\text { Falandysz 2014; Gezer and Kaygusuz 2014; Kubrová et al. 2014; Llorente-Mirandes } \\
\text { et al. 2014; Melgar et al. 2014; Nagy et al. 2014; Rakić et al. 2014; Sácký et al. 2014; } \\
\text { Širić et al. } 2014\end{array}$ & $\begin{array}{l}\text { Czech Republic, } 3 \\
\text { Germany, 1 } \\
\text { Poland, 2 } \\
\text { Romania, 1 } \\
\text { Serbia, 1 } \\
\text { Spain, 2 } \\
\text { Turkey, 1 }\end{array}$ & $\begin{array}{l}\text { Ecotoxicology and Environmental } \\
\quad \text { Safety, } 1 \\
\text { Environmental Progress \& } \\
\quad \text { Sustainable Energy, } 1 \\
\text { Environmental Science and Pollution } \\
\quad \text { Research, } 2 \\
\text { Food and Chemical Toxicology, } 1 \\
\text { Food Chemistry, } 1 \\
\text { Fungal Genetics and Biology, } 1 \\
\text { Journal of Environmental Protection } \\
\text { and Ecology, } 1 \\
\text { Journal of Environmental Science } \\
\text { and Health, Part B, } 1 \\
\text { Journal of Hazardous Materials, } 1 \\
\text { Periodicum Biologorum, } 1\end{array}$ \\
\hline 2015 & $\begin{array}{l}\text { Cordeiro et al. 2015; Dementyev et al. 2015a, b; García-Delgado et al. 2015; Falandysz and } \\
\text { Drewnowska 2015; García et al. 2015; Koroleva and Okhrimenko 2015; Krasińska and } \\
\text { Falandysz 2015; Ostos et al. 2015; Sarikurkcu et al. 2015; Schlecht and Säumel 2015; } \\
\text { Vaario et al. 2015; Zsigmond et al. } 2015\end{array}$ & $\begin{array}{l}\text { Finland, 1 } \\
\text { Germany, } 1 \\
\text { Poland, 2 } \\
\text { Romania, } 1 \\
\text { Russia, 3 } \\
\text { Spain, 4 } \\
\text { Turkey, 1 }\end{array}$ & $\begin{array}{l}\text { Acta Universitatis Sapientiae, } \\
\text { Agriculture and Environment, } 1 \\
\text { Doklady Biochemistry and } \\
\text { Biophysics, } 1 \\
\text { Ecotoxicology and Environmental } \\
\text { Safety, } 2 \\
\text { Environmental Pollution, } 1 \\
\text { Food Additives \& Contaminants: } \\
\text { Part A, } 1 \\
\text { Food Chemistry, } 1 \\
\text { Journal of Environmental Science } \\
\text { and Health, Part A, } 1 \\
\text { Journal of Food Composition and } \\
\text { Analysis, } 1 \\
\text { Journal of Hazardous Materials, } 1 \\
\text { Mycorrhiza, } 1 \\
\text { Pollution Atmosphérique, } 1 \\
\text { Radiochemistry, } 1\end{array}$ \\
\hline 2016 & $\begin{array}{l}\text { Cejpková et al. 2016; Dimitrijevic et al. 2016; Frutos et al. 2016; Gabriel et al. 2016; Kojta } \\
\text { and Falandysz 2016; Kosanić et al. 2016; Krasińska and Falandysz 2016; } \\
\text { Llorente-Mirandes et al. 2016; Melgar et al. 2016; Śirić et al. 2016a; b; Stefanović et al. } \\
\text { 2016a; b }\end{array}$ & $\begin{array}{l}\text { Croatia, } 2 \\
\text { Czech Republic, } 2 \\
\text { Poland, } 2 \\
\text { Serbia, } 4 \\
\text { Spain, } 3\end{array}$ & $\begin{array}{l}\text { Ecotoxicology and Environmental } \\
\quad \text { Safety, } 1 \\
\text { Environmental Earth Sciences, } 1 \\
\text { Environmental Pollution, } 1 \\
\text { Environmental Science and Pollution } \\
\quad \text { Research, } 4 \\
\text { European Food Research and } \\
\quad \text { Technology, } 1 \\
\text { Food and Chemical Toxicology, } 1 \\
\text { Food Chemistry, } 1 \\
\text { International Journal of } \\
\text { Environmental Science and } \\
\text { Technology, 1 } \\
\text { Journal of Food and Drug Analysis, } \\
1 \\
\text { Šumarski list, } 1\end{array}$ \\
\hline
\end{tabular}

frequently studied species of fungi. Furthermore, the article also includes the values of the highest concentrations of the most frequently studied heavy metals found in fungi. Additionally, a list of fungi species has been presented, together with their current, relevant scientific name (colloquial names, synonyms, or outdated names appear in many publications). The publications whose authors assessed the health risks arising from the consumption of contaminated mushrooms (i.e. with heavy/toxic metals) are also listed according to the different indices (Falandysz and Drewnowska 2015; Melgar et al. 2014; Zsigmond et al. 2015).

This article contains a bibliometric analysis of 200 European publications about the concentrations of selected elements in mushrooms that were published between 2001 and 2016. We evaluated these articles relying on some important aspects: the edibility of mushrooms (edible and non-edible/poisonous species), the most studied elements (type, incidence, and concentration in the fruiting body), and health risks 
related to consumption (contamination level of mushrooms with heavy metals).

\section{Materials and methods}

The articles considered in this bibliometric survey were selected from various online databases such as ScienceDirect, Springer, Scopus, and Web of Science. These databases are the main sources for monitoring the progress of scientific research. A total of 200 articles from the years 2001-2016 were analysed. Publications from consecutive years do not represent all the published material; however, an attempt was made to select the most 'popular' (article citation index) articles in a given year. We tried to collect at least ten publications from each year. Table 1 presents a list of authors covered in the literature survey. Because authors occasionally provided synonyms for the names of the same species, as well as sometimes using outdated phrases from mushroom nomenclature, we have used the current definitions from the Catalogue of Life: 2019 Annual Checklist and Index Fungorum. For example, due to the conflicting description regarding the edibility of the species Tricholoma fracticum (the mushroom is described as edible in one publication and non-edible in another), we decided to define the edibility of a species using the United Nations FAO (Boa 2004), the MycoKey 4.1 program (MK), and the following selected Internet pages: Wikipedia (W), Fungipedia (F), www.wildfooduk.com (UK), and www. mycodb.fr (MDB). The Supplementary data section contains all the numerical data concerning elements, mushroom species, and the countries present in the list. Our main task was to search for a relevant literature entry (year, location of research) and select the data of interest (element, mushroom species studied). The article was based on reviews, which were the inspiration for this work (Kalač 2010; Kalač and Svoboda 2000). These publications were most frequently based on the analyses of concentrations of individual elements in mushrooms (Mogîldea 2016; Kalač et al. 2004; Román et al. 2006), which were related to publications on the biomonitoring of certain areas for heavy metal pollution in selected mushroom species, e.g. Świsłowski and Rajfur (2018). This article is based on a systematic literature review, following the example of other bibliometric papers (Chang and Ho 2010; de Freitas and Alves-Souza 2019).

\section{Results and discussion}

The average number of publications per year was 13 . Table 2 contains a list of the ten most frequently mentioned mushroom species in the above publications.

The Boletus edulis was the most frequently studied species, and it was present in 57 articles out of 200 . The articles dealt with a total number of 492 species of edible (262) and nonedible mushrooms (226). The list included four mushroom species (Helvella leptopodra, Hypholoma pudorinus, Russula nigrescens, Suillus elegant) that were only mentioned in these publications and have not been identified elsewhere. This could have been caused by an erroneously quoted name or the use of a synonym of the approved name. In Table 2, only the edible species from the general list are shown. This confirms that European researchers focused on edible mushroom species (more than half of the 492 fungi species included in the analysed articles). The phrase 'non-edible' mushrooms signifies those that have no culinary value, those whose consumption can be hazardous to health, and poisonous ones. The species Amanita muscaria was the most frequently mentioned non-edible mushroom species (26 times).

Table 3 contains five of the most frequently occurring elements out of the 74 mentioned. The Supplementary data section contains both alkali metals, non-metals, radioisotopes, and heavy metals. The last group occurred most frequently in the list.

The majority of publications contained studies on the mushrooms' capacity for concentrating elements (e.g. migration mechanisms), or their possible harmfulness (polluted with heavy metals) when consumed by humans. The analyses of $\mathrm{Cd}, \mathrm{Pb}$, and $\mathrm{Zn}$ concentrations and their presence in mushrooms were due to the fact that many authors indicated the health-related aspects of consuming mushrooms contaminated by heavy metals (Table 4 ).

The most frequently discussed element was cadmium (Table 3). The influence of different concentrations of this element on growth and its content in Paxillus involutus was determined by the highest concentration of Cd (3964 \pm $611 \mathrm{mg} \mathrm{kg}^{-1}$ dry mass). This mushroom was isolated from its fruiting bodies at a mining site contaminated with heavy metals, in the Harz mountains, Germany (Ott et al. 2002). However, if we consider the natural cadmium contamination of mushrooms, the highest concentration was found in fungi taken from an area contaminated by a smelter in Lhota near Prríbram in the Czech Republic: the concentration of this metal in I. badia was $333 \mathrm{mg} \mathrm{kg}^{-1} \mathrm{~d}$. m. (Cejpková et al. 2016). An equally high concentration ( $325 \mathrm{mg} \mathrm{kg}^{-1} \mathrm{~d}$. m.) was recorded in Agaricus arvensis, which was collected in Slovenia. The fungi were collected in the vicinity of the largest Slovenian thermal power plant (the Šalek Valley) and near an abandoned lead smelter (the Upper Meža Valley) (Petkovšek and Pokorny 2013). The maximum concentration of $\mathrm{Cd}$ permitted by European Union regulation in cultivated A. bisporus, P. ostreatus, and L. edodes is $2.0 \mathrm{mg} \mathrm{kg}^{-1} \mathrm{~d}$. m., assuming $90 \%$ moisture, while for other mushrooms, it is $1.0 \mathrm{mg} \mathrm{kg}^{-1}$ fw (10 $\mathrm{mg} \mathrm{kg}^{-1} \mathrm{~d}$. m.) (EU 2008). It should be stressed that mushrooms collected in such areas are unfit for consumption.

The zinc concentrations in mushrooms were analysed in more than half of the publications. Most often $\mathrm{Zn}$ 
Table 2 Most frequently mentioned mushroom species in the publications

\begin{tabular}{rcc}
\hline Species & Number & Percentage of publications (\%) \\
\hline Boletus edulis & 57 & 28.5 \\
Macrolepiota procera & 49 & 24.5 \\
Cantharellus cibarius & 44 & 22.0 \\
Imleria badia & & \\
Lactarius deliciosus & 39 & 19.5 \\
Lepista nuda & 35 & 17.5 \\
Leccinum scabrum & 34 & 16.0 \\
Xerocomellus chrysenteron (Bull.) Šutara, 2008* & 32 & 15.5 \\
Agaricus bisporus & 31 & \\
Agaricus campestris & &
\end{tabular}

*The name Xerocomellus chrysenteron is already outdated concentrations are in the range of $50-150 \mathrm{mg} \mathrm{kg}^{-1} \mathrm{~d}$. m. However, a higher concentration of $\mathrm{Zn}$ was present in Sarcodon scabrosus, taken from a pine forest in Turkey $\left(4325 \pm 298 \mathrm{mg} \mathrm{kg}^{-1} \mathrm{~d}\right.$. m.). This result differed significantly from the abovementioned average concentrations presented in the literature. The concentration of $\mathrm{Zn}$ in fungi seems to be similar to, or higher than, that found in the soil. The only species known to accumulate $\mathrm{Zn}$ in a significant way is Russula atropurpurea. This species, taken from unpolluted areas in the Czech Republic and Slovakia, contained as high $\mathrm{Zn}$ as $1062 \mathrm{mg} \mathrm{kg}^{-1}$ d. m. (Borovička and Řanda 2007). The high concentrations of zinc in sporocarps of this species are related to the presence of functional peptides, which bind this metal (Leonhardt et al. 2014).

The habitat from which fungi are taken has a direct impact on the levels of contamination of mushrooms by selected elements (including heavy metals). This was also the case of Amanita citrina, taken from industrialised areas in Upper Silesia in Poland. The concentration of lead in the fungus was $895 \mathrm{mg} \mathrm{kg}^{-1} \mathrm{~d}$. m. The influence of zinc and lead smelters, which have been emitting pollutants in this area since the end of the nineteenth century, is undeniable (Krupa and Kozdrój 2004). Lead concentration in Macrolepiota procera was found to be of $171 \mathrm{mg} \mathrm{kg}^{-1} \mathrm{~d}$. m. The habitat of the fungi was contaminated with $\mathrm{Pb}$ due to former metallurgical and mining activities (Petkovšek and Pokorny 2013). The low mobility of $\mathrm{Pb}$ and its ensuing rapid accumulation in mushroom stem are the main reasons why $\mathrm{Pb}$ is found chiefly in stems rather than mushroom caps (Komárek et al. 2007). An example is the 2007 study carried out near a $\mathrm{Pb}$ smelter in the highly polluted area of Príbram in the Czech Republic. In the upper soil layer of this area, lead was measured at a concentration of $36,234 \mathrm{mg} \mathrm{kg}^{-1}$, while the concentrations in the stipe of $B$. edulis growing in this study area was found to be $165 \mathrm{mg} \mathrm{kg}^{-1}$ d. m. (Komárek et al. 2007).

The copper content of mushrooms is usually 100 $300 \mathrm{mg} \mathrm{kg}^{-1} \mathrm{~d}$. m. During the period under consideration in the analysed European literature, a very high concentration of this analyte was determined in fungi collected from unpolluted areas of the Czech Republic, which makes this level of

Table 3 The number of occurrences of individual elements in the articles

\begin{tabular}{|c|c|c|c|c|}
\hline $\begin{array}{l}\text { Chemical } \\
\text { element }\end{array}$ & Number & $\begin{array}{l}\text { Species with the highest concentration of } \\
\text { the element ( } \mathrm{mg} \mathrm{kg}^{-1} \text { dry mass) }\end{array}$ & Habitat, where the mushrooms were collected & References \\
\hline $\mathrm{Cd}$ & 108 & $\begin{array}{l}\text { Paxillus involutus (Batsch) Fr., } 1838 \\
\quad(3964 \pm 611)\end{array}$ & Laboratory - grown in a liquid medium & Ott et al. 2002 \\
\hline $\mathrm{Zn}$ & 101 & $\begin{array}{l}\text { Lepista nuda (Bull.) Cooke, } 1871 \\
\quad(4325 \pm 298)\end{array}$ & pine forest site, Çınardibi, Turkey & $\begin{array}{l}\text { Karadeniz and } \\
\quad \text { Yaprak } 2010\end{array}$ \\
\hline $\mathrm{Pb}$ & 98 & Amanita citrina Pers., $1797(895 \pm 41)$ & $\begin{array}{l}\text { Industrial desert surrounding a nonferrous (zinc and lead) works in } \\
\text { Miasteczko Slaskie, Poland }\end{array}$ & $\begin{array}{l}\text { Krupa and } \\
\text { Kozdrój } \\
2004\end{array}$ \\
\hline $\mathrm{Cu}$ & 96 & $\begin{array}{l}\text { Xerocomellus chrysenteron (Bull.) } \\
\quad \text { Šutara, } 2008 \text { (502) }\end{array}$ & $\begin{array}{l}\text { Four sites in a rural area, unpolluted region near the town of } \\
\text { Moravský Krumlov in south-western Moravia, Czech Republic }\end{array}$ & $\begin{array}{l}\text { Svoboda and } \\
\text { Chrastný } \\
2008\end{array}$ \\
\hline $\mathrm{Fe}$ & 76 & $\begin{array}{l}\text { Lycoperdon perlatum Pers., } 1796 \\
\quad(24,600 \pm 368)\end{array}$ & The province of Mugla in the South-Aegean Region of Turkey & $\begin{array}{l}\text { Sarikurkcu } \\
\quad \text { et al. } 2015\end{array}$ \\
\hline
\end{tabular}


Table 4 List of indices

\begin{tabular}{|c|c|}
\hline Indices & References \\
\hline Hazard index (HI) & Falandysz et al. 2002a; Falandysz et al. 2003a; Falandysz et al. 2003b; Zsigmond et al. 2015 \\
\hline Hazard quotient (HQ) & Zsigmond et al. 2015 \\
\hline $\begin{array}{l}\text { Provisional tolerable weekly } \\
\text { intake (PTWI) }\end{array}$ & $\begin{array}{l}\text { Blanuša et al. 2001;Çayir et al. 2010; Chudzyński et al. 2009; Chudzyński et al. 2011; Dimitrijevic et al. 2016; } \\
\text { Drewnowska et al. 2014; Dryżałowska and Falandysz 2014; Falandysz and Drewnowska 2015; Frankowska et al. } \\
\text { 2010; García et al. 2009; Giannaccini et al. 2012; Gucia et al. 2012; Gursoy et al. 2009; Komárek et al. 2007; } \\
\text { Krasińska and Falandysz 2015; Krasińska and Falandysz 2016; Larsen et al. 2002; Maćkiewicz and Falandysz } \\
\text { 2012; Malinowska et al. 2004; Miklavčič et al. 2013; Mirończuk-Chodakowska et al. 2013; Ostos et al. 2015; } \\
\text { Ouzouni et al. 2007; Petkovšek and Pokorny 2013; Rudawska and Leski 2005a; Sarikurkcu et al. 2011; } \\
\text { Sarikurkcu et al. 2012; Stefanović et al. 2016b; Svoboda et al. } 2006\end{array}$ \\
\hline Reference dose (RfD) & $\begin{array}{l}\text { Chudzyński et al. 2009; Chudzyński et al. 2011; Drewnowska et al. 2014; Dryżałowska and Falandysz 2014; } \\
\text { Falandysz and Drewnowska 2015; Frankowska et al. 2010; Krasińska and Falandysz 2016; Maćkiewicz and } \\
\text { Falandysz 2012; Melgar et al. 2014; Stefanović et al. 2016a; Zsigmond et al. } 2015\end{array}$ \\
\hline Tolerable weekly intake (TWI) & $\begin{array}{l}\text { Dimitrijevic et al. 2016; Gucia et al. 2012; Melgar et al. 2016; Ozturk et al. 2010; Schlecht and Säumel 2015; } \\
\text { Stefanović et al. 2016b }\end{array}$ \\
\hline Acceptable daily intake (ADI) & Alonso et al. 2003 \\
\hline Dietary reference intake (DRI) & Cocchi et al. 2006; Costa-Silva et al. 2011 \\
\hline $\begin{array}{l}\text { Provisional tolerable daily intake } \\
\text { (PTDI) }\end{array}$ & Sesli et al. 2008 \\
\hline $\begin{array}{l}\text { Recommended dietary allowance } \\
\text { (RDA) }\end{array}$ & Busuioc et al. 2011; Çayir et al. 2010; García et al. 2013; Stefanović et al. 2016a \\
\hline $\begin{array}{l}\text { Recommended daily intake } \\
\text { (RDI) }\end{array}$ & Aloupi et al. 2012; Dimitrijevic et al. 2016 \\
\hline Tolerable daily intake (TDI) & Aloupi et al. 2012; Stefanović et al. 2016b \\
\hline Probable daily intake (PDI) & Miklavčič et al. 2013 \\
\hline
\end{tabular}

contamination puzzling: see Table 3 (Svoboda and Chrastný 2008). A copper concentration of $427 \mathrm{mg} \mathrm{kg}^{-1} \mathrm{~d}$. m. was measured in B. edulis in Norway, where mushrooms were collected from around a copper smelter (Collin-Hansen et al. 2002). In Agaricus xanthodermus, taken from areas with geochemical characteristics determined as polymetallic ores $\mathrm{Pb}$ $\mathrm{Cu}-\mathrm{Zn}-\mathrm{Ag}$, the concentration of copper was $420 \pm 14 \mathrm{mg} \mathrm{kg}^{-1}$ d. m. (řanda and Kučera 2004). Taking fungi from such areas means that the $\mathrm{Cu}$ content may be elevated (copper concentration is usually $100-300 \mathrm{mg} \mathrm{kg}^{-1} \mathrm{~d}$. m.), taking into account the contamination of a given site (Kalač and Svoboda 2000; Kalač 2010).

The highest concentrations of iron were found in mushrooms collected in Turkey (Table 3). The high concentrations of this metal can be attributed to the industrial activity in this region. In Lepista nuda, which was collected from Türkmenbaba Mountain in the Eskișehir forest area, an $\mathrm{Fe}$ concentration of $11,460 \pm 6 \mathrm{mg} \mathrm{kg}^{-1} \mathrm{~d}$. m. was measured. The results presented in this publication, for this species of fungus, were also very high for other elements $(\mathrm{Pb}, \mathrm{Mn}$, and $\mathrm{Cu}$ ) and differed from the concentrations found in other samples of mushrooms collected from Turkey (Yamaç et al. 2007). In turn, in Omphalotus olearius, taken from the forest along the Balıkesir-Manisa highway, $9685 \mathrm{mg} \mathrm{kg}^{-1}$ dry weight of iron was found. These areas were exposed to traffic pollution for many years (Yilmaz et al. 2003).
On the basis of the literature research we carried out, it can be concluded that high concentrations of heavy metals depend on the genetic properties of a given species (the ability of individual species to accumulate analytes (hyperaccumulation) (Falandysz and Borovička 2013; Sácký et al. 2016), and on the level of contamination in the habitat from which the material for testing was sampled (Mleczek et al. 2016).

Table 4 shows a list of indices that researchers used to assess the health risks associated with the consumption of fungi contaminated by heavy metals. The choice of appropriate indices for analysis depended on the type of test performed, the species of fungus on which the test was performed, and the element whose concentration was determined.

According to the literature analysis, provisional tolerable weekly intake (PTWI) was determined most frequently. The Joint FAO/WHO Expert Committee on Food Additives (JECFA) gives tolerable intake levels for contaminants, expressed on either a daily or a weekly basis. Unlike tolerable daily intake (TDI), the introduction of the term 'weekly' is intended to emphasise the need to limit the intake of a substance over a certain period of time, given that many contaminants are not rapidly removed from the body (Herrman and Younes 1999; Türkmen and Budur 2018). In addition, it can be concluded that this parameter was increasingly used in studies over the last decade of the analysis. In the research of many of the authors, they stressed the need to assess the 
Fig. 1 Map of Europe showing the frequency of publications for individual countries

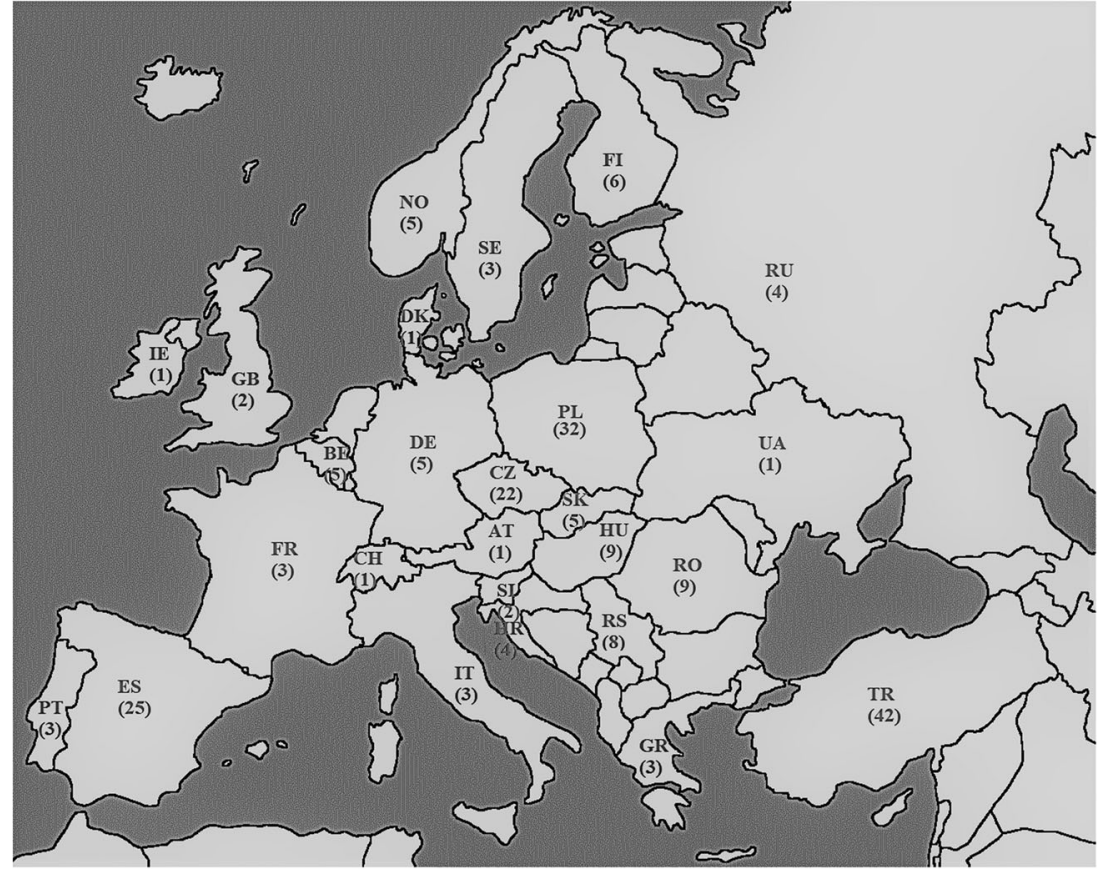

risk to human health arising from the consumption of contaminated mushrooms taken from a given area (Table 4). This was due to the great interest in research carried out on edible species, in which concentrations of, mainly, heavy metals that are dangerous to health $(\mathrm{Cd}, \mathrm{Pb}$, and $\mathrm{Hg}$ ) were determined.

Figure 1 contains a graphical representation of the countries where the discussed publications originated; for each country, the number of studies concerning sample acquisition is provided (for example, mushrooms purchased in shops or wild-grown).

Out of 26 countries, the following four were mentioned most frequently: Turkey (42), Poland (32), Spain (25), and the Czech Republic (22). Many studies about these issues have been carried out in Poland, as was shown earlier (Świsłowski and Rajfur 2017). It should be emphasised that the research teams in these countries are stable and their members produce joint publications. For example, in Poland, these works are produced mainly by Professor J. Falandysz and his teams, such as Falandysz et al. (2017).

\section{Conclusions}

As a result of this bibliometric study of 200 European publications, appearing between 2001 and 2016, on the contamination of mushrooms by selected elements, we concluded that this issue is still popular and relevant. Each year, there is an increase in the number of papers assessing the level of health risks associated with the consumption of fungi contaminated with heavy metals using different indices. The main research being done on the concentration of elements in mushrooms is connected with their heavy metal content and the risks resulting from their consumption. So it is not surprising that more than half of the 492 species of mushrooms appearing in the articles under consideration were edible. These studies were mainly concerned with taking wild fungi from various areas and determining whether selected elements were present in them. There was also no shortage of papers in which different species of mushrooms were cultured and their sorption properties in relation to selected analytes subsequently analysed. The publications also included species of fungi with a natural ability to accumulate elements, thanks to which, the mushrooms can be used for phytoremediation of contaminated soils. The highest number of publications came from Turkey, Poland, Spain, and the Czech Republic; so these countries made the largest contribution to the development of the science of elements in mushrooms and the assessment of the health risks associated with the consumption of contaminated mushrooms.

\section{Compliance with ethical standards}

Conflict of interest The authors declare that they have no conflict of interest.

Open Access This article is licensed under a Creative Commons Attribution 4.0 International License, which permits use, sharing, adaptation, distribution and reproduction in any medium or format, as long as you give appropriate credit to the original author(s) and the source, provide a link to the Creative Commons licence, and indicate if changes were made. The images or other third party material in this article are included in the article's Creative Commons licence, unless indicated otherwise in a credit line to the material. If material is not included in the article's Creative Commons licence and your intended use is not permitted by statutory regulation or exceeds the permitted use, you will 
need to obtain permission directly from the copyright holder. To view a copy of this licence, visit http://creativecommons.org/licenses/by/4.0/.

\section{References}

Adriaensen K, Van Der Lelie D, Van Laere A, Vangronsveld J, Colpaert JV (2003) A zinc-adapted fungus protects pines from zinc stress. New Phytol 161:549-555. https://doi.org/10.1046/j.1469-8137. 2003.00941.x

Alonso J, García MA, Pérez-López M, Melgar MJ (2003) The concentrations and bioconcentration factors of copper and zinc in edible mushrooms. Arch Environ Con Tox 44:180-188. https://doi.org/10. 1007/s00244-002-2051-0

Aloupi M, Koutrotsios G, Koulousaris M, Kalogeropoulos N (2012) Trace metal contents in wild edible mushrooms growing on serpentine and volcanic soils on the island of Lesvos, Greece. Ecotox Environ Safe 78:184-194. https://doi.org/10.1016/j.ecoenv.2011. 11.018

Ayaz FA, Torun H, Colak A, Sesli E, Millson M, Glew RH (2011) Macroand microelement contents of fruiting bodies of wild-edible mushrooms growing in the East Black Sea Region of Turkey. Food Nutr Sci 02:53-59. https://doi.org/10.4236/fns.2011.22007

Baldrian P, Gabriel J (2002) Copper and cadmium increase laccase activity in Pleurotus ostreatus. FEMS Microbio Lett 206:69-74. https:// doi.org/10.1016/S0378-1097(01)00519-5

Baumann N, Arnold T, Haferburg G (2014) Uranium contents in plants and mushrooms grown on a uranium-contaminated site near Ronneburg in Eastern Thuringia/Germany. Environ Sci Pollut R 21:6921-6929. https://doi.org/10.1007/s11356-013-1913-5

Benbrahim M, Denaix L, Thomas A-L, Balet J, Carnus JM (2006) Metal concentrations in edible mushrooms following municipal sludge application on forest land. Environ Pollut 144:847-854. https:// doi.org/10.1016/j.envpol.2006.02.014

Blanuša M, Kučak A, Varnai VM, Sarić MM (2001) Uptake of cadmium, copper, iron, manganese, and zinc in mushrooms (Boletaceae) from Croatian forest soil. J AOAC Int 84:1964-1971

Boa E (2004) Wild edible fungi: a global overview of their use and importance to people. Non-wood Forest Products. FAO, Rome

Borovička J, Řanda Z (2007) Distribution of iron, cobalt, zinc and selenium in macrofungi. Mycol Prog 6:249-259. https://doi.org/10. 1007/s11557-007-0544-y

Borovička J, Řanda Z, Jelínek E (2005) Gold content of ectomycorrhizal and saprobic macrofungi from non-auriferous and unpolluted areas. Mycol Res 109:951-955. https://doi.org/10.1017/ S095375620500328X

Borovička J, Řanda Z, Jelínek E (2006) Antimony content of macrofungi from clean and polluted areas. Chemosphere 64:1837-1844. https:// doi.org/10.1016/j.chemosphere.2006.01.060

Borovička J, Řanda Z, Jelínek E, Kotrba P, Dunn CE (2007) Hyperaccumulation of silver by Amanita strobiliformis and related species of the section Lepidella. Mycol Res 111:1339-1344. https:// doi.org/10.1016/j.mycres.2007.08.015

Borovička J, Kotrba P, Gryndler M, Mihaljevič M, Řanda Z, Rohovec J, Stijve T, Dunn CE (2010a) Bioaccumulation of silver in ectomycorrhizal and saprobic macrofungi from pristine and polluted areas. Sci Total Environ 408:2733-2744. https://doi.org/10.1016/j. scitotenv.2010.02.031

Borovička J, Dunn CE, Gryndler M, Mihaljevič M, Jelínek E, Rohovec J, Rohošková M, Řanda Z (2010b) Bioaccumulation of gold in macrofungi and ectomycorrhizae from the vicinity of the Mokrsko gold deposit, Czech Republic. Soil Biol Biochem 42:83-91. https:// doi.org/10.1016/j.soilbio.2009.10.003
Borovička J, Kubrová J, Rohovec J, Řanda Z, Dunn CE (2011) Uranium, thorium and rare earth elements in macrofungi: What are the genuine concentrations? BioMetals 24:837-845. https://doi.org/10.1007/ s10534-011-9435-4

Borovička J, Mihaljevič M, Gryndler M, Kubrová J, Žigová A, Hršelová H, Řanda Z (2014) Lead isotopic signatures of saprotrophic macrofungi of various origins: tracing for lead sources and possible applications in geomycology. Appl Geochem 43:114-120. https:// doi.org/10.1016/j.apgeochem.2014.02.012

Brzostowski A, Bielawski L, Orlikowska A, Plichta S, Falandysz J (2009) Instrumental analysis of metals profile in Poison Pax (Paxillus involutus) collected at two sites in Bory Tucholskie. Chem Anal (Warsaw) 54:1297 http://beta.chem.uw.edu.pl/ chemanal/PDFs/2009/CHAN2009V54P01297.pdf. Accessed 24 Aug 2019

Brzostowski A, Falandysz J, Jarzyńska G, Zhang D (2011) Bioconcentration potential of metallic elements by Poison Pax (Paxillus involutus) mushroom. J Environ Sci Heal A 46:378-393. https://doi.org/10.1080/10934529.2011.542387

Busuioc G, Elekes CC, Stihi C, Iordache S, Ciulei SC (2011) The bioaccumulation and translocation of $\mathrm{Fe}, \mathrm{Zn}$, and $\mathrm{Cu}$ in species of mushrooms from Russula genus. Environ Sci Pollut R 18:890-896. https://doi.org/10.1007/s11356-011-0446-Z

Campos JA, Tejera NA (2011) Bioconcentration factors and trace elements bioaccumulation in sporocarps of fungi collected from quartzite acidic soils. Biol Trace Elem Res 143:540-554. https://doi.org/ 10.1007/s12011-010-8853-4

Campos JA, Tejera NA, Sánchez CJ (2009) Substrate role in the accumulation of heavy metals in sporocarps of wild fungi. BioMetals 22: 835-841. https://doi.org/10.1007/s10534-009-9230-7

Carvalho ML, Pimentel AC, Fernandes B (2005) Study of heavy metals in wild edible mushrooms under different pollution conditions by $\mathrm{X}$ ray fluorescence spectrometry. Anal Sci 21:747-750. https://doi.org/ 10.2116/analsci.21.747

Çayir A, Coşkun M, Coşkun M (2010) The heavy metal content of wild edible mushroom samples collected in canakkale province, Turkey. Biol Trace Elem Res 134:212-219. https://doi.org/10.1007/s12011009-8464-0

Cejpková J, Gryndler M, Hršelová H, Kotrba P, Řanda Z, Synková I, Borovička J (2016) Bioaccumulation of heavy metals, metalloids, and chlorine in ectomycorrhizae from smelter-polluted area. Environ Pollut 218:176-185. https://doi.org/10.1016/j.envpol. 2016.08.009

Chang C, Ho Y (2010) Bibliometric analysis of financial crisis research. Afr J Bus Manage 4:3898-3910

Chudzyński K, Falandysz J (2008) Multivariate analysis of elements of Larch Bolete (Suillus grevillei) mushroom. Chemosphere 73:1230 1239. https://doi.org/10.1016/j.chemosphere.2008.07.055

Chudzyński K, Bielawski L, Falandysz J (2009) Mercury bioconcentration potential of Larch Bolete, Suillus grevillei, mushroom. Bull Environ Contam Toxicol 83:275-279. https://doi.org/10.1007/ s00128-009-9723-7

Chudzyński K, Jarzyńska G, Stefańska A, Falandysz J (2011) Mercury content and bio-concentration potential of Slippery Jack, Suillus luteus, mushroom. Food Chem 125:986-990. https://doi.org/10. 1016/j.foodchem.2010.09.102

Cocchi L, Vescovi L, Petrini LE, Petrini O (2006) Heavy metals in edible mushrooms in Italy. Food Chem 98:277-284. https://doi.org/10. 1016/j.foodchem.2005.05.068

Collin-Hansen C, Yttri KE, Andersen RA, Berthelsen BO, Steinnes E (2002) Mushrooms from two metal-contaminated areas in Norway: occurrence of metals and metallothionein-like proteins. Geochemistry: Exploration, Environment, Analysis 2:121-130. https://doi.org/10.1144/1467-787302-015

Collin-Hansen C, Andersen RA, Steinnes E (2003) Isolation and Nterminal sequencing of a novel cadmium-binding protein from 
Boletus edulis. Journal de Physique IV France 107:311-314 https:// 10.1051/jp4:20030304

Collin-Hansen C, Andersen RA, Steinnes E (2005a) Damage to DNA and lipids in Boletus edulis exposed to heavy metals. Mycol Res 109: 1386-1396. https://doi.org/10.1017/S0953756205004016

Collin-Hansen C, Andersen RA, Steinnes E (2005b) Molecular defense systems are expressed in the king bolete (Boletus edulis) growing near metal smelters. Mycologia 97:000-000. https://doi.org/10. 3852/mycologia.97.5.973

Colpaert JV, Mulle LAH, Lambaerts M, Adriaensen K, Vangronsveld J (2004) Evolutionary adaptation to $\mathrm{Zn}$ toxicity in populations of Suilloid fungi. New Phytol 162:549-559. https:// https://doi.org/10. $1111 / j .1469-8137.2004 .01037 . x$

Cordeiro F, Llorente-Mirandes T, López-Sánchez JF, Rubio R, Sánchez Agullo A, Raber G, Scharf H, Vélez D, Deversa V, Fiamegos Y, Emteborg H, Seghers J, Robouch P, de la Calle MB (2015) Determination of total cadmium, lead, arsenic, mercury and inorganic arsenic in mushrooms: outcome of IMEP-116 and IMEP-39. Food Addit Contam A 32:54-67. https://doi.org/10.1080/19440049.2014. 966336

Costa-Silva F, Marques G, Matos CC, Barros A, Nunes FM (2011) Selenium contents of Portuguese commercial and wild edible mushrooms. Food Chem 126:91-96. https://doi.org/10.1016/j.foodchem. 2010.10 .082

Cremades O, Diaz-Herrero MM, Carbonero-Aguilar P, Gutierrez-Gil JF, Fontiveros E, Rodríguez-Morgado B, Parrado J, Bautista J (2012) Preparation and characterisation of selenium-enriched mushroom aqueous enzymatic extracts (MAEE) obtained from the white button mushroom (Agaricus bisporus). Food Chem 133:1538-1543. https://doi.org/10.1016/j.foodchem.2012.02.046

Cuny D, Van Haluwyn C, Pesch R (2001) Biomonitoring of trace elements in air and soil compartments along the major motorway in France. Water Air Soil Poll 125:273-289. https://doi.org/10.1023/A: 1005278900969

Daillant O, Boilley D, Josset M, Hettwig B, Fischer HW (2013) Evolution of radiocaesium contamination in mushrooms and influence of treatment after collection. J Radioanal Nucl Ch 297:437441. https://doi.org/10.1007/s10967-012-2411-9

de Freitas VG, Alves-Souza SN (2019) A systematic literature review on big data for solar photovoltaic electricity generation forecasting. Sus Energy Technol Assess 31:54-63. https://doi.org/10.1016/j.seta. 2018.11.008

Dementyev DV, Zotina TA, Manukovsky NS, Kalacheva GS (2015a) Biosorption of $241 \mathrm{Am}$ from solution and its biochemical fractionation in the mycelium of macromycetes. Radiochemistry 57:661665. https://doi.org/10.1134/s1066362215060144

Dementyev DV, Zotina TA, Manukovsky NS, Kalacheva GS, Bolsunovsky AY (2015b) Biosorption of 241 Am from aqueous solutions and its biochemical fractionation in Pleurotus ostreatus mycelium. Dokl Biochem Biophys 460:34-36. https://doi.org/10.1134/ s160767291501010x

Demirbaş A (2001a) Concentrations of 21 metals in 18 species of mushrooms growing in the East Black Sea region. Food Chem 75:453457. https://doi.org/10.1016/S0308-8146(01)00236-9

Demirbaș A (2001b) Heavy metal bioaccumulation by mushrooms from artificially fortified soils. Food Chem 74:293-301. https://doi.org/ 10.1016/S0308-8146(01)00155-8

Demirbaș A (2002) Metal ion uptake by mushrooms from natural and artificially enriched soils. Food Chem 78:89-93. https://doi.org/10. 1016/S0308-8146(01)00389-2

Dernovics M, Stefánka Z, Fodor P (2002) Improving selenium extraction by sequential enzymatic processes for Se-speciation of seleniumenriched Agaricus bisporus. Anal Bioanal Chem 372:473-480. https://doi.org/10.1007/s00216-001-1215-5

Díaz Huerta V, Fernández Sánchez ML, Sanz-Medel A (2005) Qualitative and quantitative speciation analysis of water soluble selenium in three edible wild mushrooms species by liquid chromatography using post-column isotope dilution ICP-MS. Anal Chim Acta 538:99-105. https://doi.org/10.1016/j.aca.2005.02.033

Dimitrijevic MV, Mitic VD, Cvetkovic JS, Stankov Jovanovic VP, Mutic J, Nikolic Mandic SD (2016) Update on element content profiles in eleven wild edible mushrooms from family Boletaceae. Eur Food Res Technol 242:1-10. https://doi.org/10.1007/s00217-015-2512-0

Djingova R, Kovacheva P, Wagner G, Markert B (2003) Distribution of platinum group elements and other traffic related elements among different plants along some highways in Germany. Sci Total Environ 308:235-246. https://doi.org/10.1016/S0048-9697(02)00677-0

Drewnowska M, Nnorom I, Falandysz J (2014) Mercury in the Grisette, Amanita vaginata Fr. and soil below the fruiting bodies. J Environ Sci Heal B 49:521-526. https://doi.org/10.1080/03601234.2014. 896677

Dryżałowska A, Falandysz J (2014) Bioconcentration of mercury by mushroom Xerocomus chrysenteron from the spatially distinct locations: levels, possible intake and safety. Ecotox Environ Safe 107: 97-102. https://doi.org/10.1016/j.ecoenv.2014.05.020

Duran C, Senturk HB, Elci L, Soylak M, Tufekci M (2009) Simultaneous preconcentration of $\mathrm{Co}$ (II), $\mathrm{Ni}$ (II), $\mathrm{Cu}$ (II), and Cd (II) from environmental samples on Amberlite XAD-2000 column and determination by FAAS. J Hazard Mater 162:292-299. https://doi.org/10. 1016/j.jhazmat.2008.05.034

Elekes CC, Busuioc G, Dumitriu I (2009) Heavy metals concentration level in some wild growing species of Cortinarius genus. Annals. Food Science and Technology 10:473-477. http://www.afst.valahia. ro/images/documente/2009/1-ELEKES_BUSUIOC_DUMITRIU_ EN.pdf. Accessed 24 Aug 2019

Ertugay N, Bayhan YK (2008) Biosorption of Cr (VI) from aqueous solutions by biomass of Agaricus bisporus. J Hazard Mater 154: 432-439. https://doi.org/10.1016/j.jhazmat.2007.10.070

Ertugay N, Bayhan YK (2010) The removal of copper (II) ion by using mushroom biomass (Agaricus bisporus) and kinetic modelling. Desalination 255:137-142. https://doi.org/10.1016/j.desal.2010.01. 002

EU (2008) Commission Regulation (EC) No 629/2008 of 2 July 2008 amending Regulation (EC) No 1881/2006 setting maximum levels for certain contaminants in foodstuffs. Office J European Union 372008L173/6-9

Falandysz J (2017) Mercury accumulation of three Lactarius mushroom species. Food Chem 214:96-101. https://doi.org/10.1016/j. foodchem.2016.07.062

Falandysz J, Bielawski L (2001) Mercury content of wild edible mushrooms collected near the town of Augustow. Pol J Environ Stud 10: $67-71$

Falandysz J, Bielawski L (2007) Mercury and its bioconcentration factors in Brown Birch Scaber Stalk (Leccinum scabrum) from various sites in Poland. Food Chem 105:635-640. https://doi.org/10.1016/j. foodchem.2007.04.024

Falandysz J, Borovička J (2013) Macro and trace mineral constituents and radionuclides in mushrooms: health benefits and risks. Appl Microbiol Biotechnol 97:477-501. https://doi.org/10.1007/s00253$012-4552-8$

Falandysz J, Drewnowska M (2015) Distribution of mercury in Amanita fulva (Schaeff.) Secr. mushrooms: accumulation, loss in cooking and dietary intake. Ecotox Environ Safe 115:49-54. https://doi.org/10. 1016/j.ecoenv.2015.02.004

Falandysz J, Gucia M (2008) Bioconcentration factors of mercury by Parasol Mushroom (Macrolepiota procera). Environ Geochem Health 30:121-125. https://doi.org/10.1007/s10653-008-9133-5

Falandysz J, Gucia M, Frankowska A, Kawano M, Skwarzec B (2001a) Total mercury in wild mushrooms and underlying soil substrate from the city of Umeå and its surroundings, Sweden. B Environ Contam Tox 67:763-770. https://doi.org/10.1007/s00128-0010188-6 
Falandysz J, Szymczak K, Ichihashi H, Bielawski L, Gucia M, Frankowska A, Yamasaki S-I (2001b) ICP/MS and ICP/AES elemental analysis (38 elements) of efible wild mushrooms growing in Poland. Food Addit Contam 18:503-513 https://doi.org/10.1080/ 02652030119625

Falandysz J, Lipka K, Gucia M, Kawano M, Strumnik K, Kannan K (2002a) Accuulation factors of mercury in mushrooms from Zaborski Landscape Park, Poland. Environ Int 28:421-427. https:// doi.org/10.1016/S0160-4120(02)00067-3

Falandysz J, Gucia M, Skwarzec B, Frankowska A, Klawikowska K (2002b) Total mercury in mushrooms and underlying soil substrate from the Borecka Forest, Northeastern Poland. Arch Environ Contam Toxicol 42:145-154. https://doi.org/10.1007/s00244-0010026-1

Falandysz J, Brzostowski A, Kawano M, Kannan K, Puzyn T, Lipka K (2003a) Cncentrations of mercury in wild growing higher fungi and underlying substrate near lake Wdzydze, Poland. Water Air Soil Poll 148:127-137. https://doi.org/10.1023/A:1025422017868

Falandysz J, Kawano M, Świeczkowski A, Brzostowski A, Dadej M (2003b) Total mercury in wild-grown higher mushrooms and underlying soil from Wdzydze Landscape Park, Northern Poland. Food Chem 81:21-26. https://doi.org/10.1016/S0308-8146(02)00344-8

Falandysz J, Frankowska A, Mazur A (2007) Mercury and its bioconcentration factors in King Bolete (Boletus edulis) Bull. Fr. J Environ Sci Heal A 42:2089-2095. https://doi.org/10.1080/ 10934520701627058

Falandysz J, Kunito T, Kubota R, Bielawski L, Frankowska A, Falandysz J, Tanabe S (2008) Multivariate characterization of elements accumulated in King Bolete Boletus edulis mushroom at lowland and high mountain regions. J Environ Sci Heal A 43:1692-1699. https:// doi.org/10.1080/10934520802330206

Falandysz J, Sapkota A, Mędyk M, Feng X (2017) Rare earth elements in parasol mushroom Macrolepiota procera. Food Chem 221:24-28. https://doi.org/10.1016/j.foodchem.2016.10.047

Figueiredo E, Soares ME, Baptista P, Castro M, Bastos ML (2007) Validation of an electrothermal atomization atomic absorption spectrometry method for quantification of total chromium and chromium (VI) in wild mushrooms and underlying soils. J Agr Food Chem 55: 7192-7198. https://doi.org/10.1021/jf0710027

Fomina MA, Alexander IJ, Colpaert JV, Gadd GM (2005) Solubilization of toxic metal minerals and metal tolerance of mycorrhizal fungi. Soil Biol Biochem 37:851-866. https://doi.org/10.1016/j.soilbio. 2004.10.013

Frankowska A, Ziółkowska J, Bielawski L, Falandysz J (2010) Profile and bioconcentration of minerals by King Bolete (boletus edulis) from the Płocka Dale in Poland. Food Addi Contam B 3:1-6. https://doi.org/10.1080/19440040903505232

Frutos I, García-Delgado C, Gárate A, Eymar E (2016) Biosorption of heavy metals by organic carbon from spent mushroom substrates and their raw materials. Int J Environ Sci Te 13:2713-2720. https://doi.org/10.1007/s13762-016-1100-6

Gabriel J, Švec K, Kolihová D, Tlustoš P, Száková J (2016) Translocation of mercury from substrate to fruit bodies of Panellus stipticus, Psilocybe cubensis, Schizophyllum commune and Stropharia rugosoannulata on oat flakes. Ecotox Environ Safe 125:184-189. https://doi.org/10.1016/j.ecoenv.2015.12.009

García MA, Alonso J, Melgar MJ (2005) Agaricus macrosporus as a potential bioremediation agent for substrates contaminated with heavy metals. J Chem Technol Biot 80:325-330. https://doi.org/ $10.1002 /$ jctb. 1203

García MA, Alonso J, Melgar MJ (2009) Lead in edible mushrooms. Levels and bioaccumulation factors. J Hazard Mater 167:777-783. https://doi.org/10.1016/j.jhazmat.2009.01.058

García MA, Alonso J, Melgar MJ (2013) Bioconcentration of chromium in edible mushrooms: influence of environmental and genetic factors. Food Chem Toxicol 58:249-254. https://doi.org/10.1016/j. fct.2013.04.049

García MA, Alonso J, Melgar MJ (2015) Radiocaesium activity concentrations in macrofungi from Galicia (NW Spain): influence of environmental and genetic factors. Ecotox Environ Safe 115:152-158. https://doi.org/10.1016/j.ecoenv.2015.02.005

García-Delgado C, Jiménez-Ayuso N, Frutos I, Gárate A, Eymar E (2013) Cadmium and lead bioavailability and their effects on polycyclic aromatic hydrocarbons biodegradation by spent mushroom substrate. Environ Sci Pollut R 20:8690-8699. https://doi.org/10. 1007/s11356-013-1829-0

García-Delgado C, Yunta F, Eymar E (2015) Bioremediation of multipolluted soil by spent mushroom (Agaricus bisporus) substrate: polycyclic aromatic hydrocarbons degradation and $\mathrm{Pb}$ availability. J Hazard Mater 300:281-288. https://doi.org/10.1016/j.jhazmat. 2015.07.008

Gençcelep H, Uzun Y, Tunçtürk Y, Demirel K (2009) Determination of mineral contents of wild-grown edible mushrooms. Food Chem 113:1033-1036. https://doi.org/10.1016/j.foodchem.2008.08.058

Gezer K, Kaygusuz O (2014) An assessment of the heavy metal content of various wild edible mushrooms in the Denizli Province, Turkey. J Environ Prot Ecol 15:425-432. https://docs.google.com/a/jepejournal.info/viewer?a=v\&pid=sites\&srcid=amVwZS1qb3 VybmFs Lm luZm 98 a m Vw ZS 1 q b 3 VybmFs fG d 4 Oj ZhMjFjN2Q2MTYwNWE4MDQ. Accessed 24 Aug 2019

Giannaccini G, Betti L, Palego L, Mascia G, Schmid L, Lanza M, Mela A, Fabbrini L, Biondi L, Lucacchini A (2012) The trace element content of top-soil and wild edible mushroom samples collected in Tuscany, Italy. Environ Monit Assess 184:7579-7595. https://doi. org/10.1007/s10661-012-2520-5

Gonzálvez A, Llorens A, Cervera ML, Armenta S, de la Guardia M (2009) Non-chromatographic speciation of inorganic arsenic in mushrooms by hydride generation atomic fluorescence spectrometry. Food Chem 115:360-364. https://doi.org/10.1016/j.foodchem. 2008.11.088

Gorbunova IA, Koutzenogii KP, Koval'skaya GA, Chankina OV, Savchenko TI (2009) Elemental composition of mushrooms from Gorny Altai. Contemp Probl Ecol 2:46-50. https://doi.org/10.1134/ s1995425509010081

Gramss G, Voigt KD (2013) Clues for regulatory processes in fungal uptake and transfer of minerals to the basidiospore. BiolTrace Elem Res 154:140-149. https://doi.org/10.1007/s12011-013-97193

Gryndler M, Hršelová H, Soukupová L, Borovička J (2012) Silver release from decomposed hyperaccumulating Amanita solitaria fruit-body biomass strongly affects soil microbial community. BioMetals 25 : 987-993. https://doi.org/10.1007/s10534-012-9564-4

Gucia M, Jarzyńska G, Rafał E, Roszak M, Kojta AK, Osiej I, Falandysz J (2012) Multivariate analysis of mineral constituents of edible Parasol Mushroom (Macrolepiota procera) and soils beneath fruiting bodies collected from Northern Poland. Environ Sci Pollut Res 19:416-431. https://doi.org/10.1007/s11356-011-0574-5

Guillén J, Baeza A, Ontalba MA, Míguez MP (2009) ${ }^{210} \mathrm{~Pb}$ and stable lead content in fungi: its transfer from soil. Sci Total Environ 407: 4320-4326. https://doi.org/10.1016/j.scitotenv.2009.03.025

Gursoy N, Sarikurkcu C, Cengiz M, Solak MH (2009) Antioxidant activities, metal contents, total phenolics and flavonoids of seven Morchella species. Food Chem Toxicol 47:2381-2388. https://doi. org/10.1016/j.fct.2009.06.032

Gwynn JP, Nalbandyan A, Rudolfsen G (2013) ${ }^{210} \mathrm{Po},{ }^{210} \mathrm{~Pb},{ }^{40} \mathrm{~K}$ and ${ }^{137} \mathrm{Cs}$ in edible wild berries and mushrooms and ingestion doses to man from high consumption rates of these wild foods. J Environ Radioactiv 116:34-41. https://doi.org/10.1016/j.jenvrad.2012.08. 016

Hatvani N, Mécs I (2003) Effects of certain heavy metals on the growth, dye decolorization, and enzyme activity of Lentinula edodes. Ecotox 
Environ Safe 55:199-203. https://doi.org/10.1016/S0147-6513(02) 00133-1

Herrman JL, Younes M (1999) Background to the ADI/TDI/PTWI. Regul Toxicol Pharm 30:S109-S113. https://doi.org/10.1006/rtph. 1999.1335

Isildak Ö, Turkekul I, Elmastas M, Tuzen M (2004) Analysis of heavy metals in some wild-grown edible mushrooms from the middle black sea region, Turkey. Food Chem 86:547-552. https://doi.org/ 10.1016/j.foodchem.2003.09.007

Isildak Ö, Turkekul I, Elmastas M, Aboul-Enein HY (2007) Bioaccumulation of heavy metals in some wild-grown edible mushrooms. Anal Lett 40:1099-1116. https://doi.org/10.1080/ 00032710701297042

Işiloğlu M, Yilmaz F, Merdivan M (2001a) Concentrations of trace elements in wild edible mushrooms. Food Chem 73:169-175. https:// doi.org/10.1016/S0308-8146(00)00257-0

Ișiloğlu M, Merdivan M, Yilmaz F (2001b) Heavy metal contents in some macrofungi collected in the northwestern part of Turkey. Arch Environ Con Tox 41:1-7. https://doi.org/10.1007/s002440010215

Johansson EM, Fransson PMA, Finlay RD, van Hees PAW (2008) Quantitative analysis of exudates from soil-living basidiomycetes in pure culture as a response to lead, cadmium and arsenic stress. Soil Biol Biochem 40:2225-2236. https://doi.org/10.1016/j.soilbio. 2008.04.016

Kalač P (2009) Chemical composition and nutritional value of European species of wild growing mushrooms: a review. Food Chem 113:9 16. https://doi.org/10.1016/j.foodchem.2008.07.077

Kalač P (2010) Trace element contents in European species of wild growing edible mushrooms: a review for the period 2000-2009. Food Chem 122:2-15. https://doi.org/10.1016/j.foodchem.2010.02.045

Kalač P, Svoboda L (2000) A review of trace element concentrations in edible mushrooms. Food Chem 69:273-281. https://doi.org/10. 1016/S0308-8146(99)00264-2

Kalač P, Svoboda L, Havlíčková B (2004) Contents of cadmium and mercury in edible mushrooms. J Appl Biomed 2:15-20. https:// doi.org/10.32725/jab.2004.002

Karadeniz Ö, Yaprak G $(2010){ }^{137} \mathrm{Cs},{ }^{40} \mathrm{~K}$, alkali-alkaline earth element and heavy metal concentrations in wild mushrooms from Turkey. $\mathrm{J}$ Radioanal Nucl Ch 285:611-619. https://doi.org/10.1007/s10967010-0575-8

Kojta AK, Falandysz J (2016) Soil-to-mushroom transfer and diversity in total mercury content in two edible Laccaria mushrooms. Environ Earth Sci 75:1264. https://doi.org/10.1007/s12665-016-6072-9

Komárek M, Chrastný V, Śtíchová J (2007) Metal/metalloid contamination and isotopic composition of lead in edible mushrooms and forest soils originating from a smelting area. Environ Int 33:677684. https://doi.org/10.1016/j.envint.2007.02.001

Konuk M, Afyon A, Yağiz D (2006) Chemical composition of some naturally growing and edible mushrooms. Pak J Bot 38:799-804. http://www.pakbs.org/pjbot/PDFs/38(3)/PJB38(3)799.pdf. Accessed 24 Aug 2019

Koroleva Y, Vakhranyova,O, Okhrimenko M (2015) Accumulation of trace elements by wild mushrooms in West part of Russia (SouthEastern Baltic). Pollution Atmosphérique 226:1-11. https://doi.org/ 10.4267/pollution-atmospherique.4989

Kosanić M, Ranković B, Rančić A, Stanojković T (2016) Evaluation of metal concentration and antioxidant, antimicrobial, and anticancer potentials of two edible mushrooms Lactarius deliciosus and Macrolepiota procera. J Food Drug Anal 24:477-484. https://doi. org/10.1016/j.jfda.2016.01.008

Krasińska G, Falandysz J (2015) Mercury in Hazel Bolete Leccinum griseum and soil substratum: distribution, bioconcentration and dietary exposure. J Environ Sci Heal A 50:1259-1264. https://doi.org/ 10.1080/10934529.2015.1055151

Krasińska G, Falandysz J (2016) Mercury in Orange Birch Bolete Leccinum versipelle and soil substratum: bioconcentration by mushroom and probable dietary intake by consumers. Environ Sci Pollut Res 23:860-869. https://doi.org/10.1007/s11356-015-5331-8

Krpata D, Fitz W, Peintner U, Langer I, Schweiger P (2009) Bioconcentration of zinc and cadmium in ectomycorrhizal fungi and associated aspen trees as affected by level of pollution. Environ Pollut 157:280-286. https://doi.org/10.1016/j.envpol. 2008.06.038

Krupa P, Kozdrój J (2004) Accumulation of heavy metals by ectomycorrhizal fungi colonizing birch trees growing in an industrial desert soil. World J Microb Biot 20:427-430. https://doi.org/10. 1023/B:WIBI.0000033067.64061.f3

Kubrová J, Žigová A, Řanda Z, Rohovec J, Gryndler M, Krausová I, Dunn CE, Kotrba P, Borovička J (2014) On the possible role of macrofungi in the biogeochemical fate of uranium in polluted forest soils. J Hazard Mater 280:79-88. https://doi.org/10.1016/j.jhazmat. 2014.07.050

Kula İ, Solak MH, Uğurlu M, Ișiloğlu M, Arslan Y (2011) Determination of mercury, cadmium, lead, zinc, selenium and iron by ICP-OES in mushroom samples from around thermal power plant in Muğa, Turkey. B Environ Contam Tox 87:276-281. https://doi.org/10. 1007/s00128-011-0357-1

Larsen EH, Andersen NL, Møller A, Petersen A, Mortensen GK, Petersen $\mathrm{J}$ (2002) Monitoring the content and intake of trace elements from food in Denmark. Food Addit Contam 19:33-46. https://doi.org/10. 1080/02652030110087447

Leonhardt T, Sácký J, Šimek P, Šantrůček J, Kotrba P (2014) Metallothionein-like peptides involved in sequestration of $\mathrm{Zn}$ in the $\mathrm{Zn}$-accumulating ectomycorrhizal fungus Russula atropurpurea. Metallomics 6:1693. https://doi.org/10.1039/C4MT00141A

Llorente-Mirandes T, Barbero M, Rubio R, López-Sánchez JF (2014) Occurrence of inorganic arsenic in edible Shiitake (Lentinula edodes) products. Food Chem 158:207-215. https://doi.org/10. 1016/j.foodchem.2014.02.081

Llorente-Mirandes T, Llorens-Muñoz M, Funes-Collado V, Sahuquillo À, López-Sánchez JF (2016) Assessment of arsenic bioaccessibility in raw and cooked edible mushrooms by a PBET method. Food Chem 194:849-856. https://doi.org/10.1016/j.foodchem.2015.08.047

Lodenius M, Soltanpour-Gargari A, Tulisalo E (2002) Cadmium in forest mushrooms after application of wood ash. B Environ Contam Tox 68:211-216. https://doi.org/10.1007/s001280240

Maćkiewicz D, Falandysz J (2012) Total mercury in Yellow Knights (Tricholoma equstre) mushrooms and beneath soils. Bull Environ Contam Toxicol 89:755-758. https://doi.org/10.1007/s00128-0120757-x

Malinowska E, Szefer P, Falandysz J (2004) Metals biaccumulation by bay bolete, Xerocomus badius, from selected sites in Poland. Food Chem 84:405-416. https://doi.org/10.1016/S0308-8146(03)002504

Malinowska E, Szefer P, Bojanowski R (2006) Radionuclides content in Xerocomus badius and other commercial mushrooms from several regions of Poland. Food Chem 97:19-24. https://doi.org/10.1016/j. foodchem.2005.02.048

Marzano FN, Bracchi PG, Pizzetti P (2001) Radioactive and conventional pollutants accumulated by edible mushrooms (Boletus sp.) are useful indicators of species origin. Environ Res 85:260-264. https://doi. org/10.1006/enrs.2001.4233

Mattila P, Ko K (2001) Contents of vitamins, mineral elements , and some phenolic compounds in cultivated mushrooms. J Agr Food Chem 49:2343-2348. https://doi.org/10.1021/jf001525d

Melgar MJ, Alonso J, García MA (2007) Removal of toxic metals from aqueous solutions by fungal biomass of Agaricus macrosporus. Sci Total Environ 385:12-19. https://doi.org/10.1016/j.scitotenv.2007. 07.011

Melgar MJ, Alonso J, García MA (2009) Mercury in edible mushrooms and underlying soil: bioconcentration factors and toxicological risk. 
Sci Total Environ 407:5328-5334. https://doi.org/10.1016/j. scitotenv.2009.07.001

Melgar MJ, Alonso J, García MA (2014) Total contents of arsenic and associated health risks in edible mushrooms, mushroom supplements and growth substrates from Galicia (NW Spain). Food Chem Toxicol 73:44-50. https://doi.org/10.1016/j.fct.2014.08.003

Melgar MJ, Alonso J, García MA (2016) Cadmium in edible mushrooms from NW Spain: bioconcentration factors and consumer health implications. Food Chem Toxicol 88:13-20. https://doi.org/10.1016/j. fct.2015.12.002

Mendil D, Uluözlü ÖD, Hasdemir E, Çağlar A (2004) Determination of trace elements on some wild edible mushroom samples from Kastamonu, Turkey. Food Chem 88:281-285. https://doi.org/10. 1016/j.foodchem.2004.01.039

Mendil D, Uluözlü ÖD, Tüzen M, Hasdemir E, Sari H (2005) Trace metal levels in mushroom samples from Ordu, Turkey. Food Chem 91: 463-467. https://doi.org/10.1016/j.foodchem.2004.06.028

Mietelski JW, Baeza AS, Guillen J, Buzinny M, Tsigankov N, Gaca P, Jasińska M, Tomankiewicz E (2002) Plutonium and other alpha emitters in mushrooms from Poland, Spain and Ukraine. Appl Radiat Isotopes 56:717-729. https://doi.org/10.1016/S09698043(01)00281-0

Miklavčič A, Mazej D, Jaćimović R, Dizdareviǒ T, Horvat M (2013) Mercury in food items from the Idrija Mercury Mine area. Environ Res 125:61-68. https://doi.org/10.1016/j.envres.2013.02.008

Milinkovic M, Raicevic V, Lalevic B, Golubovic Curguz V, Jovanovic L (2012) Content of heavy metals in carpophores of wild mushroom (Boletus edulis). Proceedings of 6th Central European Congress on Food, Novi Sad, Serbia, pp 378-381. http://www.fins.uns.ac.rs/ uploads/zbornici/CEFood-proceedings2012.pdf. Accessed 24 August 2019

Mirończuk-Chodakowska I, Socha K, Witkowska A, Zujko M, Borawska M (2013) Cadmium and lead in wild edible mushrooms from the Eastern Region of Poland's 'green lungs'. Pol J Environ Stud 22: $1759-1765$

Mititelu M, Nicolescip TO, Ionita CA, Nicolescu F (2012) Heavy metals analysis of some wild edible mushrooms. J Environ Prot Ecol 13: 875-879. https://docs.google.com/a/jepe-journal.info/viewer?a= $\mathrm{v} \& \mathrm{pid}=$ sites \& srcid $=\mathrm{amVwZS} 1 \mathrm{qb} 3 \mathrm{VybmFsLmluZm98am}$ VwZS1qb3 VybmFsfGd4Ojc4ZTY5ZTc2OTg2ZjNkMDc. Accessed 24 Aug 2019

Mleczek M, Magdziak Z, Gąsecka M, Niedzielski P, Kalač P, Siwulski M, Rzymski P, Zalicka S, Sobieralski K (2016) Content of selected elements and low-molecular-weight organic acids in fruiting bodies of edible musroom Boletus edulis (Fr.) Fr. from unpolluted and polluted areas. Environ Sci Pollut Res 23:20609-20618. https:// doi.org/10.1007/s11356-016-7222-z

Mogîldea D (2016) Bioaccumulation of toxic heavy metals in mushrooms - a review. Oltenia Journal for Studies in Natural Sciences 32:157163. http://biozoojournals.ro/oscsn/cont/32_2/22_Mogaldea.pdf. Accessed 24 Aug 2019

Moilanen M, Fritze H, Nieminen M, Piirainen S, Issakainen J, Piispanen J (2006) Does wood ash application increase heavy metal accumulation in forest berries and mushrooms? Forest Ecol Manag 226:153160. https://doi.org/10.1016/j.foreco.2006.01.033

Moreno-Rojas R, Díaz-Valverde MA, Arroyo BM, González TJ, Capote CJB (2004) Mineral content of gurumelo (Amanita ponderosa). Food Chem 85:325-330. https://doi.org/10.1016/S0308-8146(03) 00264-4

Muller LAH, Lambaerts M, Vangronsveld J, Colpaert JV (2004) AFLPbased assessment of the effects of environmental heavy metal pollution on the genetic structure of pioneer populations of Suillus luteus. New Phytol 164:297-303. https://doi.org/10.1111/j.14698137.2004.01190.x

Nagy B, Szilagyi B, Majdik C, Katona G, Indolean C, Măicăneanu A (2014) Cd (II) and Zn (II) biosorption on Lactarius piperatus macrofungus: equilibrium isotherm and kinetic studies. Environmental Progress \& Sustainable Energy 33:1158-1170. https://doi.org/10.1002/ep11897

Nikkarinen M, Mertanen E (2004) Impact of geological origin on trace element composition of edible mushrooms. J Food Compos Anal 17:301-310. https://doi.org/10.1016/j.jfca.2004.03.013

Nováčková J, Fiala P, Chrastný V, Svoboda L, Kalač P (2007) Contents of mercury, cadmium and lead in edible mushrooms and in underlying substrates from a rural area with an occurrence of serpentines and amphiboles. Ekol Bratislava 26:322-329. http://147.213.211.222/ node/2317. Accessed 24 Aug 2019

Omil B, Piñeiro V, Merino A (2007) Trace elements in soils and plants in temperate forest plantations subjected to single and multiple applications of mixed wood ash. Sci Total Environ 381:157-168. https:// doi.org/10.1016/j.scitotenv.2007.04.004

Osobová M, Urban V, Jedelský PL, Borovička J, Gryndler M, Ruml T, Kotrba P (2011) Three metallothionein isoforms and sequestration of intracellular silver in the hyperaccumulator Amanita strobiliformis. New Phytol 190:916-926. https://doi.org/10.1111/j. 1469-8137.2010.03634.x

Ostos C, Pérez-Rodríguez F, Arroyo BM, Moreno-Rojas R (2015) Study of mercury content in wild edible mushrooms and its contribution to the Provisional Tolerable Weekly Intake in Spain. J Food Compos Anal 37:136-142. https://doi.org/10.1016/j.jfca.2014.04.014

Ott T, Fritz E, Polle A, Schützendübel A (2002) Characterisation of antioxidative systems in the ectomycorrhiza-building basidiomycete Paxillus involutus (Bartsch) Fr. and its reaction to cadmium. FEMS Microbiol Ecol 42:359-366. https://doi.org/10.1016/S01686496(02)00328-8

Ouzouni PK, Veltsistas PG, Paleologos EK, Riganakos KA (2007) Determination of metal content in wild edible mushroom species from regions of Greece. J Food Compos Anal 20:480-486. https:// doi.org/10.1016/j.jfca.2007.02.008

Ouzouni PK, Petridis D, Koller WD, Riganakos KA (2009) Nutritional value and metal content of wild edible mushrooms collected from West Macedonia and Epirus, Greece. Food Chem 115:1575-1580. https://doi.org/10.1016/j.foodchem.2009.02.014

Özcan MM, Dursun N, Al Juhaimi FY (2013) Heavy metals intake by cultured mushrooms growing in model system. Environl Monit Assess 185:8393-8397. https://doi.org/10.1007/s10661-013-3181-8

Ozturk I, Sahan S, Sahin U, Ekici L, Sagdic O (2010) Bioactivity and mineral contents of wild-grown edible Morchella conica in the Mediterranean Region. J Verbrauch Lebens 5:453-457. https://doi. org/10.1007/s00003-010-0625-8

Perkiömäki J, Kiikkilä O, Moilanen M, Issakainen J, Tervahauta A, Fritze $\mathrm{H}$ (2003) Cadmium-containing wood ash in a pine forest: effects on humus microflora and cadmium concentrations in mushrooms, berries, and needles. Can J Forest Res 33:2443-2451. https://doi. org/10.1139/x03-169

Petkovšek SAS, Pokorny B (2013) Lead and cadmium in mushrooms from the vicinity of two large emission sources in Slovenia. Sci Total Environ 443:944-954. https://doi.org/10.1016/j.scitotenv. 2012.11.007

Radulescu C, Stihi C, Busuioc G, Gheboianu AI, Popescu IV (2010a) Studies concerning heavy metals bioaccumulation of wild edible mushrooms from industrial area by using spectrometric techniques. B Environ Contam Tox 84:641-646. https://doi.org/10.1007/ s00128-010-9976-1

Radulescu C, Stihi C, Busuioc G, Popescu IV, Gheboianu AI, Cimpoca VG (2010b) Evaluation of essential elements and heavy metal levels in fruiting bodies of wild mushrooms and their substrate by EDXRF spectrometry and FAA spectrometry. Rom Biotech Lett 15:54445456. https://e-repository.org/rbl/vol.15/iss.4/11.pdf. Accessed 24 Aug 2019

Radulescu C, Stihi C, Popescu IV, Busuioc G, Gheboianu AI, Cimpoca VG, Dulamă ID, Diaconescu M (2010c) Determination of heavy 
metals content in wild mushr ooms and soil by EDXRF and FAAS techniques. Ovidius University Annals of Chemistry 21:9-14. http:// anale-chimie.univ-ovidius.ro/anale-chimie/chemistry/2010-1/full/ 2_Radulescu.pdf. Accessed 24 Aug 2019

Rakić M, Karaman M, Forkapić S, Hansman J, Kebert M, Bikit K, Mrdja D (2014) Radionuclides in some edible and medicinal macrofungal species from Tara Mountain, Serbia. Environ Sci Pollut R 21: 11283-11292. https://doi.org/10.1007/s11356-014-2967-8

Řanda Z, Kučera J (2004) Trace elements in higher fungi (mushrooms) determined by activation analysis. J Radioanal Nucl Ch 259:99107. https://doi.org/10.1023/B:JRNC.0000015813.27926.32

Rieder SR, Brunner I, Horvat M, Jacobs A, Frey B (2011) Accumulation of mercury and methylmercury by mushrooms and earthworms from forest soils. Environ Pollut 159:2861-2869. https://doi.org/ 10.1016/j.envpol.2011.04.040

Román M, Boa E, Woodward S (2006) Wild-gathered fungi for health and rural livelihoods. P Nutr Soc 65:190-197. https://doi.org/10. 1079/pns2006491

Rudawska M, Leski T (2005a) Macro- and microelemnt contents in fruting bodies of wild mushrooms from the Notecka forest in west-central Poland. Food Chem 92:499-506. https://doi.org/10. 1016/j.foodchem.2004.08.017

Rudawska M, Leski T (2005b) Trace elemnts in fruiting bodies of ectomycorrhizal fungi growing in Scots pine (Pinus sylvestris L.) stands in Poland. Sci Total Environ 399:103-115. https://doi.org/10. 1016/j.scitotenv.2004.08.002

Ruytinx J, Nguyen H, Van Hees M, Op De Beeck M, Vangronsveld J, Carleer R, Colpaert JV, Adriaensen K (2013) Zinc export results in adaptive zinc tolerance in the ectomycorrhizal basidiomycete Suillus bovinus. Metallomics 5:1225-1233. https://doi.org/10.1039/ c3mt00061c

Sácký J, Leonhardt T, Borovička J, Gryndler M, Briksí A, Kotrba P (2014) Intracellular sequestration of zinc, cadmium and silver in Hebeloma mesophaeum and characterization of its metallothionein genes. Fungal Genet Biol 67:3-14. https://doi.org/10.1016/j.fgb. 2014.03.003

Sácký J, Leonhardt T, Kotrba P (2016) Functional analysis of two genes coding for distinct cation diffusion facilitators of the ectomycorrhizal Zn-accumulating fungus Rusula atropurpurea. Biometals 29:349-363. https://doi.org/10.1007/s10534-016-9920-x

Sarikurkcu C, Tepe B, Semiz DK, Solak MH (2010) Evaluation of metal concentration and antioxidant activity of three edible mushrooms from Mugla, Turkey. Food Chem Toxicol 48:1230-1233. https:// doi.org/10.1016/j.fct.2009.12.033

Sarikurkcu C, Copur M, Yildiz D, Akata I (2011) Metal concentration of wild edible mushrooms in Soguksu National Park in Turkey. Food Chem 128:731-734. https://doi.org/10.1016/j.foodchem.2011.03. 097

Sarikurkcu C, Tepe B, Solak MH, Cetinkaya S (2012) Metal concentrations of wild edible ushrooms from Turkey. Ecolo Food Nutr 51: 346-363. https://doi.org/10.1080/03670244.2012.674448

Sarikurkcu C, Tepe B, Kocak MS, Uren MC (2015) Metal concentration and antioxidant activity of edible mushrooms from Turkey. Food Chem 175:549-555. https://doi.org/10.1016/j.foodchem.2014.12. 019

Schlecht MT, Säumel I (2015) Wild growing mushrooms for the Edible City? Cadmium and lead content in edible mushrooms harvested within the urban agglomeration of Berlin, Germany. Environ Pollut 204:298-305. https://doi.org/10.1016/j.envpol.2015.05.018

Şen I, Alli H, Çöl B (2012) Boron contents of some wild-growing mushrooms collected from the vicinity of boron mines in Balikesir, Turkey. Biol Trace Elem Res 145:233-239. https://doi.org/10. 1007/s12011-011-9170-2

Sesli E (2006) Trace element contents of some selected fungi in the ecosystem of Turkey. Fresen Environ Bull 15:518-523. https:// www.prt-parlar.de/download_feb_2006/. Accessed 24 Aug 2019
Sesli E, Dalman Ö (2006) Concentrations of trace elements in fruiting bodies of wild growing fungi in Rize Province of Turkey. Asian J Chem 18:2179-2184. www.asianjournalofchemistry.co.in/User/ ViewFreeArticle.aspx? ArticleID=18_3_73.Accessed 24 Aug 2019

Sesli E, Tuzen M (2006) Micro- and macroelement contents of edible, wild growing mushrooms in Artvin Province of Turkey. Asian J Chem 18:1423-1429. www.asianjournalofchemistry.co.in/User/ ViewFreeArticle.aspx? ArticleID=18 2 101. Accessed 24 August 2019

Sesli E, Tuzen M, Soylak M (2008) Evaluation of trace metal contents of some wild edible mushrooms from Black sea region, Turkey. J Hazard Mater 160:462-467. https://doi.org/10.1016/j.jhazmat. 2008.03.020

Severoglu Z, Sumer S, Yalcin B, Leblebici Z, Aksoy A (2013) Trace metal levels in edible wild fungi. Int J Environ Sci Te 10:295-304. https://doi.org/10.1007/s13762-012-0139-2

Širić I, Kos I, Bedeković D, Kaić A, Kasap A (2014) Heavy metals in edible mushroom Boletus reticulatus Schaeff. Collected from Zrin mountain, Croatia. Period Biol 116:319-322. Retrieved from https:// hrcak.srce.hr/file/199348. Accessed 24 Aug 2019

Širić I, Humar M, Kasap A, Kos I, Mioč B, Pohleven F (2016a) Heavy metal bioaccumulation by wild edible saprophytic and ectomycorrhizal mushrooms. Environ Sci Pollut R 23:1823918252. https://doi.org/10.1007/s11356-016-7027-0

Širić I, Kasap A, Kos I, Markota T, Tomić D, Poljak M (2016b) Heavy metal contents and bioaccumulation potential of some wild edible mushrooms. Šumar List 140:29-37. https://www.sumari.hr/sumlist/ pdf/201600290.pdf. Accessed 24 Aug 2019

Sivrikaya H, Bacak L, Saraçbașı A, Toroğlu I, Eroğlu H (2002) Trace elements in Pleurotus sajor-caju cultivated on chemithermomechanical pulp for bio-bleaching. Food Chem 79: 173-176. https://doi.org/10.1016/S0308-8146(02)00128-0

Škrbić B, Milovac S, Matavulj M (2012) Multielement profiles of soil, road dust, tree bark and wood-rotten fungi collected at various distances from high-frequency road in urban area. Ecol Indic 13:168177. https://doi.org/10.1016/j.ecolind.2011.05.023

Slávik M, Tóth T, Harangozo L', Árvay J, Stanovič R, Miššík J (2013) The content of mercury in edible mushrooms from Middle Spiš area. J Microbiol Biotechn Food Sci 2:2115-2124. https://www.jmbfs.org/ wp-content/uploads/2013/06/114 jmbs slavik fbp f.pdf. Accessed 24 Aug 2019

Soeroes C, Kienzl N, Ipolyi I, Dernovics M, Fodor P, Kuehnelt D (2005) Arsenic uptake and arsenic compounds in cultivated Agaricus bisporus. Food Control 16:459-464. https://doi.org/10.1016/j. foodcont.2004.05.007

Soylak M, Saraçoğlu S, Tüzen M, Mendil D (2005) Determination of trace metals in mushroom samples from Kayseri, Turkey. Food Chem 92:649-652. https://doi.org/10.1016/j.foodchem.2004.08. 032

Stefanović V, Trifković J, Djurdjić S, Vukojević V, Tešić Ž, Mutić J (2016a) Study of silver, selenium and arsenic concentration in wild edible mushroom Macrolepiota procera, health benefit and risk. Environ Sci Pollut R 23:22084-22098. https://doi.org/10.1007/ s11356-016-7450-2

Stefanović V, Trifković J, Mutić J, Tešić Ž (2016b) Metal accumulation capacity of parasol mushroom (Macrolepiota procera) from Rasina region (Serbia). Environ Sci Pollut R 23:13178-13190. https://doi. org/10.1007/s11356-016-6486-7

Stihi C, Busuioc G, Radulescu C, Elekes C, Ciulei S (2011) Determination of $\mathrm{Fe}$ and $\mathrm{Zn}$ accumulation in leafy vegetables and mushrooms using energy dispersive X-Ray fluorescence technique. Bulletin UASVM Agriculture 68:143-147. https://journals. usamvcluj.ro/index.php/agriculture/article/view/6539. Accessed 24 Aug 2019 
Svoboda L, Chrastný V (2008) Levels of eight trace elements in edible mushrooms from a rural area. Food Addit Contam A 25:51-58. https://doi.org/10.1080/02652030701458519

Svoboda L, Kalač P (2003) Contamination of two edible Agaricus spp. mushrooms growing in a town with cadmium, lead, and mercury. B Environ Contam Tox 71:123-130. https://doi.org/10.1007/s00128003-0138-6

Svoboda L, Kalač P, Špička J, Janoušková D (2002) Leaching of cadmium, lead and mercury from fresh and differently preserved edible mushroom, Xerocomus badius, during soaking and boiling. Food Chem 79:41-45. https://doi.org/10.1016/S0308-8146(02)00175-9

Svoboda L, Havlíčková B, Kalač P (2006) Contents of cadmium, mercury and lead in edible mushrooms growing in a historical silvermining area. Food Chem 96:580-585. https://doi.org/10.1016/j. foodchem.2005.03.012

Świsłowski P, Rajfur M (2017) Bioaccumulation of elements in mushrooms - review of selected literature (in polish). Proc ECOpole 11: 591-599. https://doi.org/10.2429/proc.2017.11(2)067

Świsłowski P, Rajfur M (2018) Mushrooms as biomonitors of heavy metals contamination in forest areas. Ecol Chem Eng S 25:557568. https://doi.org/10.1515/eces-2018-0037

Tasdemir G, Yamac M, Cabuk A, Yildiz Z (2008) Selection of newly isolated mushroom strains for tolerance and biosorption of zin in vitro. J Microbiol Biotechn 18:483-489. http://www.jmb.or.kr/ journal $/$ view.html?book $=$ Journal\&tops $=\&$ start $=0 \&$ scale $=50 \&$ key $=$ all\&key_word $=\&$ Vol $=18 \&$ Num $=3 \& \mathrm{PG}=\&$ year $1=\&$ year $2=\&$ sort $=$ publish_Date+desc\&aut_box $=Y \&$ sub_box $=Y \&$ sos_box $=\&$ key box $=\&$ pub box $=$ Y \&abs box $=\& \bmod =$ vol $\&$ mnum $=1649 \&$ multi $\%$ $5 \mathrm{~B} \% 5 \mathrm{D}=\overline{2} 501 \& \mathrm{multi} \% 5 \mathrm{~B} \% 5 \mathrm{D}=752 \& \mathrm{multi} \% 5 \mathrm{~B} \% 5 \mathrm{D}=$ 1800\&multi\%5B $\% 5 \mathrm{D}=1614 \&$ multi\%5B $\% 5 \mathrm{D}=1630 \&$ multi $\% 5 \mathrm{~B} \%$ 5D=436\&multi\%5B\%5D=2268\&multi\%5B $\% 5 \mathrm{D}=1910 \&$ multi\% $5 \mathrm{~B} \% 5 \mathrm{D}=1952 \&$ multi $\% 5 \mathrm{~B} \% 5 \mathrm{D}=1761 \&$ multi\%5B $\% 5 \mathrm{D}=$ 1568\&multi\%5B $\% 5 \mathrm{D}=1522 \&$ multi $\% 5 \mathrm{~B} \% 5 \mathrm{D}=1649 \&$ multi $\% 5 \mathrm{~B} \%$ 5D $=2403 \&$ multi $\% 5 \mathrm{~B} \% 5 \mathrm{D}=1932 \&$ multi $\% 5 \mathrm{~B} \% 5 \mathrm{D}=2206 \&$ multi $\%$ $5 \mathrm{~B} \% 5 \mathrm{D}=716 \&$ multi $\% 5 \mathrm{~B} \% 5 \mathrm{D}=2304 \& \mathrm{multi} \% 5 \mathrm{~B} \% 5 \mathrm{D}=$ 574\&multi\%5B $\% 5 \mathrm{D}=376 \&$ multi\%5B $\% 5 \mathrm{D}=662 \&$ multi $\% 5 \mathrm{~B} \%$ 5D=1223\&multi\%5B \%5D =1332\&multi\%5B \%5D $=2322 \&$ multi $\%$ $5 \mathrm{~B} \% 5 \mathrm{D}=848 \& \mathrm{multi} \% 5 \mathrm{~B} \% 5 \mathrm{D}=546 \&$ multi $\% 5 \mathrm{~B} \% 5 \mathrm{D}=$ 1119\&multi\%5B \%5D $=847 \&$ multi $\% 5 \mathrm{~B} \% 5 \mathrm{D}=1307 \&$ multi $\% 5 \mathrm{~B} \%$ $5 \mathrm{D}=2405$. Accessed 24 Aug 2019

Turkekul I, Elmastas M, Tüzen M (2004) Determination of iron, copper, manganese, zinc, lead, and cadmium in mushroom samples from Tokat, Turkey. Food Chem 84:389-392. https://doi.org/10.1016/ S0308-8146(03)00245-0

Türkmen M, Budur D (2018) Heavy metal contaminations in edible wild mushroom species from Turkey's Black Sea region. Food Chem 254:256-259. https://doi.org/10.1016/j.foodchem.2018.02.010

Tüzen M (2003) Determination of heavy metals in soil, mushroom and plant samples by atomic absorption spectrometry. Microchem J 74: 289-297. https://doi.org/10.1016/S0026-265X(03)00035-3

Tüzen M, Soylak M (2005) Mercury contamination in mushroom samples from Tokat, Turkey. B Environ Contam Tox 74:968-972. https://doi.org/10.1007/s00128-005-0674-3

Tüzen M, Sesli E, Soylak M (2007) Trace element levels of mushroom species from East Black Sea region of Turkey. Food Control 18: 806-810. https://doi.org/10.1016/j.foodcont.2006.04.003

Vaario LM, Pennanen T, Lu J, Palmén J, Stenman J, Leveinen J, Kilpeläinen P, Kitunen V (2015) Tricholoma matsutake can absorb and accumulate trace elements directly from rock fragments in the shiro. Mycorrhiza 25:325-334. https://doi.org/10.1007/s00572014-0615-2

Vetter J (2003a) Data on sodium content of common edible mushrooms. Food Chem 81:589-593. https://doi.org/10.1016/S0308-8146(02) 00501-0
Vetter J (2003b) Chemical composition of fresh and conserved Agaricus bisporus mushroom. Eur Food Res Technol 217:10-12. https://doi. org/10.1007/s00217-003-0707-2

Vetter J (2004) Arsenic content of some edible mushroom species. Eur Food Res Technol 219:71-74. https://doi.org/10.1007/s00217-0040905-6

Vetter J (2005a) Lithium content of some common edible wild-growing mushrooms. Food Chem 90:31-37. https://doi.org/10.1016/j. foodchem.2004.03.019

Vetter J (2005b) Mineral composition of basidiomes of Amanita species. Mycol Res 109:746-750.https://doi.org/10.1017/ S0953756205002455

Vetter J, Berta E (2005) Mercury content of the cultivated mushroom Agaricus bisporus. Food Control 16:113-116. https://doi.org/10. 1016/j.foodcont.2003.12.004

Vinichuk M (2012) Selected metals in various fractions of soil and fungi in a swedish forest. ISRN Ecol 2012:1-7. https://doi.org/10.5402/ 2012/521582

Weeks CA, Croasdale M, Osborne MA, Hewitt L, Miller PF, Robb P, Baxter MJ, Warriss PD, Knowles TG (2006) Multi-element survey of wild edible fungi and blackberries in the UK. Food Addit Contam 23:140-147. https://doi.org/10.1080/02652030500386184

Yağiz D, Konuk M, Afyon A, Kök SM (2008) Minor element and heavy metal content of edible wild mushrooms native to Bolu, North-West Turkey. Fres Environ Bull 17:249-252. https://www.prt-parlar.de/ download feb 2008/. Accessed 24 Aug 2019

Yamaç M, Yildiz D, Sarikürkcü C, Çelikkollu M, Solak MH (2007) Heavy metals in some edible mushrooms from the Central Anatolia, Turkey. Food Chem 103:263-267. https://doi.org/10. 1016/j.foodchem.2006.07.041

Yeșil ÖF, Yildiz A, Yavuz Ö (2004) Level of heavy metals in some edible and poisonous macrofungi of Diyarbakir Region in Turkey. B Environ Contam Tox 73:853-861. https://doi.org/10.1007/s00128004-0505-y

Yilmaz F, Isiloglu M, Merdivan M (2003) Heavy metal levels in some macrofungi. Turk J Bot 27:45-56. http://journals.tubitak.gov.tr/ botany/issues/bot-03-27-1/bot-27-1-4-0105-6.pdf. Accessed 24 Aug 2019

Zhang D, Frankowska A, Jarzyńska G, Kojta A, Drewnowska M, Wydmańska D, Bielawski L, Wang J, Falandysz J (2010) Metals of King Bolete (Boletus edulis) Bull.: Fr. collected at the same site over two years. Afr J Agr Res 5:3050-3055

Zhang D, Zhang Y, Morawska E, Bielawski L, Krasińska G, Drewnowska M, Pankavec S, Szymańska K, Falandysz J (2013) Trace elements in Leccinum scabrum mushrooms and topsoils from Kłodzka Dale in Sudety Mountains, Poland. J Mt Sci 10:621-627. https://doi.org/10.1007/s11629-013-2384-3

Zimmermannová K, Svoboda L, Kalač P (2001) Mercury, cadmium, lead and copper contents in fruiting bodies of selected edible mushrooms in contaminated Middle Spiš region, Slovakia. Ekol Bratislava 20: 440-446. http://147.213.211.222/node/2850. Accessed 24 Aug 2019

Zsigmond AR, Varga K, Harangi S, Baranyai E, Urák I (2015) Elemental profile of edible mushrooms from a forest near a major Romanian city. Acta Universitatis Sapientiae, Agriculture and Environment 7: 98-107. https://doi.org/10.1515/ausae-2015-0009

Žunić ZS, Mietelski JW, Błażej S, Gaca P, Tomankiewicz E, Ujić P, Čeliković I, Čuknić O, Demajo M (2008) Traces of DU in samples of environmental bio-monitors (non-flowering plants, fungi) and soil from target sites of the Western Balkan region. J Environ Radioactiv 99:1324-1328. https://doi.org/10.1016/j.jenvrad.2008. 04.005

Publisher's note Springer Nature remains neutral with regard to jurisdictional claims in published maps and institutional affiliations. 